\title{
Öğrenmeyi Öğrenme Üzerine Ev Temelli Aile Katılımı Çalıșması
}

\author{
Gülten Feryal GÜNDÜZ*
}

\begin{abstract}
Öz: Bu eylem araştırması çalışmasının amacı velilerin çocuklarının öğrenmeyi öğrenme becerilerinin geliştirilmesini desteklemede kullanabilecekleri bir veli eğitimi çalışması gerçekleştirmektir. Sekiz veli ve bu velilerin çocukları araştırmanın katılımcılarını oluşturmuştur. Araştırma verilerinin toplanmasında öğrenme stilleri envanteri, ders ses kayıtları, alan notları, araştırmacı günlüğü, whatsapp grubu, öğrenci çalışma kağıtları, geçerlik-güvenirlik komitesi toplantı kayıtları ile odak grup görüşmesi ve yarı yapılandırılmış görüşmeler kullanılmıştır. Elde edilen temel sonuçlar şunlardır: (a) Velilerin veli eğitimi çalışmasına katılımlarında devamlılığın sağlanmasında ve motive olmalarında öğrenme ihtiyaçlarının saptanması ve yüz yüze dersler yanında sosyal ağın da kullanılması etkili olmuştur. (b) Veliler destekleme çalışmalarında genellikle anlamlandırma, yineleme ve örgütleme stratejilerinin kullanımını anlamayı izleme ve duyuşsal stratejilere göre daha kolay gerçekleştirmişlerdir. (c)Veli eğitimi çalışması velilerin çocuklarının öğrenmelerini nasıl destekleyebileceklerini öğrenmelerinde, kendilerini daha yeterli hissetmelerinde ve aile katılımı çalışmalarını yapmaya olan isteklerinin artmasında etkili olmuştur. (d) Veli eğitimi çalışması çocukların akademik başarıları, özgüvenleri, sınıf içi derse katılımları ve öğrenmeye yönelik tutumlarında olumlu değişikliklere neden olmuştur.
\end{abstract}

Anahtar Sözcükler: Aile Katılımı, Veli Eğitimi Çalışması, Ortaokul Öğrenci Velileri, Öğrenmeyi Öğrenme, Eylem Araştırması

\section{A Parental Engagement Study on Learning to Learn}

\begin{abstract}
The aim of this action research study is to realised a parent education study that parents can utilize in order to support the development of children's skills in learning to learn. Eight parents and their children formed the participants of the study. Learning styles inventory, voice recordings of the lessons, field notes, researcher diary, WhatsApp group, student study papers, validity-reliability committee meeting records, focus group and semi-structured interviews were used to collect the research data. The main conclusions are as follows: (a) determining the learning needs and using the social network in addition to face-to-face lessons were effective in ensuring the continuity of parents' participation and their motivation in the family education study. (b) Parents generally used meaningfulness, rehearsal and organization strategies more easily compared to comprehension monitoring and affective strategies. (c) The family education study has helped parents learn how to support their children's learning, feel more competent and increase their willingness to take part in parental engagement. (d) The family education study has led to positive changes in children's academic achievement, self-confidence, active participation and attitudes towards learning.
\end{abstract}

Keywords: Parental Engagement, Parent Education Study, Parents of Secondary School Students, Learning to Learn, Action Research 
Aile katılımı en genel şekliyle anne-babaların çocuklarının gelişim ve eğitimlerine katkıda bulunmaları için düzenlenmiş etkinliklerin bütünü olarak tanımlanabilir (Ömeroğlu ve Can Yaşar, 2005, akt. Erdoğan ve Demirkasımoğlu, 2010). Alanyazındaki aile katılımı sınıflamaları ve modelleri incelendiğinde aile katılımının okul temelli ve ev temelli olmak üzere iki şekilde ele alındığı görülmektedir (Goodall, 2018; Hester, 1989; Hoover-Dempsey ve Sandler, 1995; Jeynes, 2018; Keith ve diğerleri, 1998; Lawson, 2003). Ev temelli katılımda (parental engagement) evde gerçekleştirilen eğitim etkinlikleri, ev ödevlerine yardım, evde uygun öğrenme ortamının sağlanması, okul ve eğitime karşı olumlu tutum ve beklentilere sahip olmasını sağlama, öğrenmekten hoşlanma ve öğrenmeye karşı güdüleme, ebeveynlik için okul desteğinin sağlanması gibi stratejiler yer almaktadır (Eipstein, 1995; Fan ve Chen, 2001; Göktürk ve Dinçkal, 2018; Rogers, Theule, Ryan, Adams ve Keating, 2009). Okul temelli katılımı (parental involvement) ise ev ve okul arasındaki iletişim, velinin okulda bulunması ve okul etkinliklerine katılımı ile veli-öğretmen görüşmelerini kapsamaktadır (DeSpain, Conderman ve Gerzel-Short, 2018; Göktürk ve Dinçkal, 2018; Rogers ve diğerleri, 2009).

Aile katılımının sağlanması okul öncesi dönemden liseye kadar tüm eğitim basamaklarında önemli olmaktadır. Aile katılımı çalışmalarının ne düzeyde ve nasıl olması gerektiği ise ilgili eğitim basamağına göre farklılaşmaktadır. Alanyazındaki araştırmalar aile katılımının öğrencinin yaş düzeyi arttıkça azaldığını göstermektedir (DeSpain ve diğerleri, 2018; Jeynes, 2014; Noel, Stark ve Redford, 2016). Alanyazında karşılaşılan bu duruma karşıtlık olarak ortaokulda ve lisede aile katılımının önemli olduğunu vurgulayan pek çok çalışma bulunmaktadır. Jeynes (2014), aile katılımına ilişkin yapılan meta-analiz çalışmalarının sonuçlarını değerlendirdiği çalışmasında aile katılımının etki boyutunun ilköğretime göre ortaokullarda azalmasına rağmen, ortaokul düzeyinde hâlâ ailelerin evde çocuğunun öğrenmesini desteklemeye katılımlarının istatistiksel olarak önemli olduğu sonucunu elde etmiştir. Kim ve Hill (2015) de ilköğretime nazaran ortaokulda aile katılımının, başarı ile daha yakından ilişkili olduğunu ve okul başarısına ilişkin daha uzun dönemli uygulamaları kapsadığını vurgulamaktadırlar. Okul ve ev temelli aile katılımının azalması ortaokul ve lise öğrencilerinin akademik başarılarını ve gidişatını olumsuz yönde etkilemektedir (DeSpain, Conderman ve Gerzel-Short, 2018). Ergenlerin akademik performanslarında yaşanan düşüşlerin ve okuldan ayrılma noktasında artan risklerin engellenmesinde, ergenlik süresince, aile katılımı önemli bir ebeveynlik stratejisi olabilmektedir (Bhargava ve Whiterspoon, 2015; Wang ve Eccles, 2012). Özellikle düşük okul başarısı olan öğrencilerin velileri, çocuklarını destekleyebilme noktasında daha fazlasını yapabileceklerine inanmakta ve nasıl etkili katılım sağlayabileceklerine ilişkin daha fazla bilgi istemektedirler (Bridgeland, Dilulio, Streeter, Mason ve Civic, 2008; Trusty, 1998, akt. Hill, Whiterspoon ve Bartz, 2018).

Ortaokul ve liselerde aile katılımının az olmasının önemli nedenlerinden birinin de çocukların ortaokula başlangıç yaşı ile ergenlik başlangıçlarının birbirine yakın olmasıdır. Ortaokul ve lise ilkokuldan farklı bir yapıya sahiptir (McGill, Huhges, Alicea ve Way, 2012). Ergenlik çocukların fiziksel, sosyal ve duyuşsal özeliklerinde önemli değişimlerin olduğu bir dönemdir (Lerner ve Steinberg, 2009). Ergenlik ile birlikte çocukların istekleri artmakta, daha fazla bağımsızlığa ve özerkliğe ihtiyaç duymaktadırlar (Jeynes, 2014; Kreider, Caspe, Kennedy ve Weiss, 2007). Ortaokula başladıklarında çocukların okul ile olan deneyimleri de değişmektedir (Hill ve Tyson, 2009). Ortaokulda öğretmen ve arkadaş çevresi genişlemekte, derslere ilişkin kendilerinin karar vermeleri gereken durumlar, bağımsız olarak kullanmaları gereken öğrenme stratejileri, soyut düşünme yetenekleri, deneyimlerinden öğrenmeleri, sorgulamaları ve farklı bakış açılarını dikkate almaları artmaktadır (Hill ve Chao, 2009; Keating, 2004).

Ergenlerin bu gelişimsel özelliklerindeki değişimlere bağlı olarak öğretmen, arkadaş ve ailesi ile olan iletişiminde de farklılıklarla karşılaşılmaktadır (Lionetti ve diğerleri, 2018). Ergenler otonom olma isteklerine bağlı olarak ailelerinin okul etkinliklerine katılmalarında ya da akademik çalışmalarını kontrol etmelerinde daha az istekli olmaktadırlar (Park ve Holloway, 2013). Tüm bu durumlar ise velilerin çocuklarını bu değişen davranışları ile nasıl başa çıkacaklarının yanında çocuklarının öğrenmelerini akademik anlamda nasıl destekleyecekleri konusunda da zorlanmalarına neden olmaktadır (DeVito, 2011; Hornby, 2011; Lionetti ve diğerleri, 2018). Çocuğun ilkokuldan çıkıp ortaokula ya da liseye geçiş yapmasıyla birlikte aileler ergenlerin eğitimine katılma yöntemlerini de değiştirmeli; onların akademik gelişimlerini destekleyecek daha etkili yollar bulmalıdırlar (Bhargava ve Whiterspoon, 2015; Hill ve Chao, 2009; Hill ve diğerleri, 2018; Smetana, 
2011). Ergenlikte etkili ebeveynlik için otonominin ve izlemenin düzeyi artırılırken doğrudan davranışın kontrolü azaltılmalıdır. Onların karar verme becerilerinin ve sorumluluk duygularının geliştirilmesine yönelik aile katılımı çalışmaları yapılmalıdır (Bhargava ve Whiterspoon, 2015; Bridgeland ve diğerleri, 2008). Çocuklar büyüdükçe aile katılımı çalışmalarında onlarla akademik başarılarından beklentilerinin neler olduğuna ilişkin konuşma ve hedef, amaç ve akademik başarının anlamı konusunda bir anlayış oluşturma başarılarını olumlu etkilemektedir (Hill ve Tyson, 2009; Jeynes, 2007). Akademik sosyalleşme de ergenlere ilişkin gerçekleştirilecek aile katılımında etkili olmaktadır. Akademik sosyalleşme ergenlerin bağlılığa ihtiyaçlarının desteklenmesine devam edilmesini sağlarken aynı zamanda otonomluklarındaki gelişimsel ihtiyaçlarını da karşılamada etkili bir aile katılımı şeklidir (Park ve Holloway, 2013). Velilerin çocuklarının notlara ilişkin beklentilerine yönelik ilişki kurmayı, onların eğitsel ve mesleki isteklerini artırmayı, öğrenme stratejilerini tartışmayı ve gelecek için planlarını formüle etmelerini sağlamayı gerektirmektedir (Hill ve Tyson, 2009).

Özellikle ergenlik döneminde daha ön plana çıkan otonomi, çocukların özdüzenleyici öğrenme ve öğrenmeyi öğrenme gibi kavramlar ile de yakından ilişkilidir (Çubukçu, 2009; Saks ve Leijen, 2018; Soenens ve Vansteenkiste, 2005; Thomas, Muls, Backer ve Lombaerts, 2019; Waeytens, Lens ve Vandenberghe, 2002; Wolters, 2003). Ergenlikle birlikte çocukların öğrenmelerinde daha aktif katılımcı olma, amaçlarını belirleme ve kendi öğrenmelerinin sorumluluğunu alma yeterlikleri de artmaktadır (Jodl, Michael, Malanchuk, Eccles ve Sameroff, 2001; Seiffge-Krenke, Kiuru ve Nurmi, 2002, akt. Hill ve diğerleri, 2018). Waeytens ve diğerleri (2002) "öğrenmeyi öğrenme" yi dar ve geniş anlamlı olmak üzere iki şekilde tanımlamaktadırlar. Öğrenmeyi öğrenme, dar anlamda düşünüldüğünde çalışma becerileri, stratejiler ve teknikler; geniş anlamda düşünüldügünde ise üst düzey bilişsel becerilere odaklanmaktadır. Wall'un (2012) Claxton'dan (2004) aktardığına göre öğrenmeyi öğretmenin ve öğrenmeyi öğrenmenin ileriki aşamaları üstbilişsel stratejiler ile yansıtıcı ve stratejik düşünme becerileri kullanma, araştırma toplumu olma ve öğrenmede işbirliği yapmayı kapsarken; ilk aşamaları öğrenme stratejileri, teknikler ve öğrenme stillerinin farkında olunması ve kullanılması, bunların nasıl kullanılacağının öğrencilere açıklanması gibi daha basit düzeyleri kapsamaktadır. Öğrenmeyi öğrenme ile ilgili alanyazın incelendiğinde öğrenmeyi öğrenmede öğrenenin öğrenme tercihlerinin, öğrenme stillerinin, bilişsel, duyuşsal ve üstbilişsel öğrenme stratejilerinin önemli olduğu görülmektedir (Fredriksson ve Hoskins, 2006; Grønmo, 2006; Moreno ve Martin, 2007). Kloosterman (2006) da öğrenmeyi öğrenme yetiştirme programları düzenlenirken katılımcıların amaçlarına ulaşmalarında kolaylaştırıcıların önemli olduğunu belirtmekte ve bu programlar düzenlenirken katılımcıların özel öğrenme ihtiyaçları ile öğrenme stillerinin de dikkate alınması gerekliliğini belirtmektedir (akt. Habok, 2015).

Eğitim bilimciler öğrencilerin bağımsız öğrenenler olmasını amaçlamalarına rağmen buna yönelik aileleri ile birlikte bu amaca ilişkin hiç bir çalışma yapmamaktadırlar (Goodall, 2018). Thomas ve diğerleri (2019) de otonomda önemli bir yeri olan ve "öğrenmeyi öğrenme" ile ilişkili olan özdüzenleyici öğrenmenin nasıl olması gerektiği ile ilgili alanyazında sınıf içi araştırmalar fazlasıyla olmakla birlikte; okul dışında nasıl olması gerektiğinin hala araştırılmakta olduğunu belirtmektedir. Öğrencilerin bu becerilerinin ortaya çıkarılmasında ve kullanmalarının sağlanmasında ailelerin de rol model olması ve destekleyici olması önemli olmaktadır (Patall, Cooper ve Robinson, 2008; Shinogaya, 2017; Thomas ve diğerleri, 2019). Harrison'a (2003) göre de "Eğitim bir bütünselliktir; anne-baba, toplum, okul, öğretmen ve akranlar bu bütünün parçalarıdır ve hepsi birer eğitmendir. Dolayısıyla bütünün parçaları birbirini desteklemedikçe başarıya ulaşılamayacaktır." (Akt. Özgan ve Aydın, 2010). Bu nedenle velilere çocuklarının özellikle ergenlik döneminde çok önemli olan otonom öğrenmelerini evde nasıl destekleyebilecekleri konusunda bir veli eğitimi çalışması uygulanmasının faydalı olacağı düşünülmüştür. Fine (1980, akt. Stanley, Vaterlaus, Tulane ve Beckert, 2017) aile eğitimini ebeveynliğe ilişkin katılımcları bilgilendirmek, farkındalık oluşturmak ve beceri kazandırmak amaçlı hazırlanmış sistematik bir program olarak tanımlamaktadır. Bir başka tanıma göre ise aile eğitimi, ailelere yönelik çocuklarının bireysel ihtiyaçlarını ve gelişimlerini ve aynı zamanda kendi görev ve sorumluluklarını anlamalarına yardımcı olmak için tasarlanan ve çocuklar ve aileler için olumlu sonuçları artırmayı amaçlayan araç ve stratejilerin sunulmasını sağlayan programlardır (Child Welfare Information Gateway, 2019). Alanyazındaki aile eğitimi programlarının genellikle iletişim, sınırları belirleme, özgüveni sağlama, duyguları yönetme, teknoloji, olumsuz öğrenci davranışların engellenmesi, cinsiyet ve madde bağımlılığına yönelik 
olduğu görülmektedir (Collins ve Fetsch, 2012; Stanley ve diğerleri, 2017). Ailelere yönelik öğrenmeyi öğrenme konusunda gerçekleştirilmiş bir veli eğitimi çalışmasına rastlanmamıştır. Alanyazındaki aile katılımına yönelik yapılan araştırmaların büyük bir kısmının aile katılımının bazı demografik özellikler, aile stilleri, akademik başarı ve öğrencinin gelişimsel özellikleri ile ilişkisine yönelik olduğu görülmektedir (Ashby, 2006; Bhargava ve Whiterspoon, 2015; Çayak, 2013; Fan ve Chen, 2001; Garcia, Fernandez ve RuizGallardo, 2018; Gillies, 2007; Hill ve Tyson, 2009; Jeynes, 2007; Sheldon, 2007; Starr, 2011; Şad, 2012; Wang ve Sheikh- Khalil, 2014; Wilder, 2014). Bir kısmı ise aile katılımında karşılaşılan sorunlara ve bu katılımın nasıl artırılabileceğine odaklanmıştır (Hornby ve Lafaele, 2011; Hornby ve Blackwell, 2018; Williams ve Sanchez, 2013; Jzeirski ve Wall, 2017). Eğitimbilimcilerin de ifade ettiği gibi ev temelli aile katılımının nasıl olması gerektiği konusunda uygulamalı çalışmalar yok denecek kadar azdır (Froiland ve Davison, 2014; Jezierski ve Wall, 2017; Matejevic, Jovanovic ve Jovanovic, 2014; Moroni, Dumont, Trautwein, Niggli ve Baeriswyl, 2015). Jezeirski ve Wall (2017) da Kanada ebeveyn dergilerindeki aile katılımı ile ilgili makalelerin analizini yaparak 1993-1995 ile 2013-2015 dönemlerini karşılaştırdıkları araştırmalarında ikinci dönemde aile katılımının neden önemli olduğunun değil, nasıl gerçekleştirilmesi gerektiğinin öne çıktığını belirtmişlerdir. Bunun yanında Chen ve Gregory (2009) de aile katılımının ergenlikte nasıl olması gerektiğine yönelik yapılan çalışmaların azlığını vurgulamaktadırlar. Tüm bu gereklilik ve sorun durumlarından hareketle bu araştırmada ortaokul öğrencilerine öğrenmeyi öğrenme temel becerilerini kazandırmaya yönelik bir veli eğitimi çalışmasının gerçekleştirilmesi amaçlanmıştır. Bu genel amaç doğrultusunda şu sorulara yanıt aranmıştır:

Araştırma Sorusu 1: Öğrenme stillerine dayalı bir veli eğitimi çalışması nasıl tasarlanmalıdır?

Araştırma Sorusu 2: Velilerin veli eğitimi çalışması ile destekleme çalışmalarında, çocuklarının öğrenme stillerine uygun öğrenme stratejilerini kullanma becerileri nasıl geliştirilebilir?

Araştırma Sorusu 3: Velilerin gerçekleştirilen öğrenme stillerine dayalı veli eğitimi çalışmasına yönelik görüşleri nelerdir?

Araştırma Sorusu 4: Öğrencilerin gerçekleştirilen öğrenme stillerine dayalı veli eğitimi çalışmasına yönelik görüşleri nelerdir?

\section{Yöntem}

Araştırma katılımcı eylem araştırması biçiminde desenlenmiştir. Katılımcı eylem araştırmasının araştırmacıya yüklediği görev ve sorumluluklar dikkate alınarak bu araştırmada araştırmacı öğrenme ortamını düzenlemiş, eylem planlarını geliştirmiş, etkinlikleri hazırlamış, dersteki etkinliklerle ilgili ses kayıtları tutmuş, derslerden önce ve derslerden sonra günlük tutmuş, elde ettiği verilerin analizini yaparak elde edilen bulgular doğrultusunda yeni eylem planlarını geliştirmiş ve uygulamaya koymuştur.

\section{Araştırma Süreci ve Uygulama Ortamı}

Araştırma iki aşamada gerçekleştirilmiştir. Eylem araştırmasının uygulanması öncesi olarak adlandırılan ilk aşama 4.10 - 8.11.2018 tarihleri arasında bir buçuk ay süre ile her hafta 2-3 saat arası olmak üzere toplam 18 saatlik bir ders süresini kapsamaktadır. Eylem araştırmasının uygulanma süreci öncesi olan bu aşamada araştırmacı velilere öğrenme-öğretme, öğrenmeyi öğrenme, öğrenme stilleri ve öğrenme stratejileri hakkında genel bilgiler vermiştir.

Araştırmanın ikinci aşaması ise eylem araştırmasının uygulanması sürecidir. Mills (2003) ve Johnson (2005)'a göre eylem araştırmasının ilk aşaması, problemin ya da araştırma konusunun tanımlanmasıdır. Araştırmacı Türkiye'de bir ortaokulda öğretmenlik yapmaktadır. Bununla birlikte bir ortaokulun 6.sınıf şubesinin şube rehber öğretmenliği görevini yürütmektedir. Türkiye'de şube rehber öğretmeni, ilgili sınıfın rehberlik çalışmalarını yürütmektedir. Bu bağlamda o sınıftaki öğrencilerin sorunları ile ilgilenme, öğrencilerin akademik başarılarını ve davranışlarını gözlemleme, öğrenci tanıma çizelgesi oluşturma şube rehber öğretmenin görevlerinden bazılarıdır. Araştırmacının şube rehber öğretmenliğini yürüttüğü sınıftaki öğrencilerin velileri ile gerçekleştirdiği veli toplantısında veliler araştırmacıya çocuklarının öğrenmelerine akademik anlamda yardımcı olamamaktan rahatsız olduklarını ifade etmişlerdir. Bu sorun durumu karşısında 
araştırmacı, bu velilere yönelik akademik anlamda bir destekleme çalışması yapmayı düşünmüştür. Gönüllü katılmak isteyen sekiz veli ile sonrasında odak grup görüşmesi gerçekleştirilerek öğrenme ihtiyaçlarının belirlenmesi amaçlanmıştır. Bu velilerin büyük bir çoğunluğu çocuklarının ders çalışmak istememelerini ve çocuklarını akademik anlamda neden destekleyemediklerini ifade etmişlerdir. Velilerin görüşlerinden bazıları şunlardır:

“Ben oğluma otur ders çalışacağız diyorum. Önce tamam diyor ama sonra bir türlü yerinde oturamıyor. Sürekli kıpır kıpır.... Öyle çalışılmaz diyorum ama dinleyen yok..."

“Benimki (oğlundan bahsediyor) çalışırken sürekli bir şeyler yemek istiyor. Oğlum öyle çalışılmaz sürekli bir şey yemek dikkatini dağıtır diyorum ama dinlemiyor..."

"Oturuyor masaya sözde çalışacağız. Sağına bakıyor, yukarılara bakıyor iki okuyor o kadar. Sadece okumakla olmaz diyorum. Ben bazı dersleri nasıl çalıştıracağımı zaten bilmiyorum ama o da nasıl çalışacağını bilmiyor çoğu zaman..."

Velilerin toplantıda bu ve benzeri ifadeleri, araştırmacıya onların çocuklarının ne şekilde öğrenmek istediklerinin farkında olmadıkları için öğrenmelerini destekleyemediklerini düşündürmüştür. Araştırmacı odak grup görüşmesinde velilere öğrenmeyi öğrenme, öğrenme stili ve öğrenme stratejileri kavramlarının ne demek olduğunu ve bu konudaki bilgilerini sormuştur. Velilerin tamamının bu kavramlar hakkında bilgisinin olmadığı görülmüştür. Benzer soruları araştırmacı derste çocuklara sormuştur. Çocukların hiç biri öğrenme stili ve öğrenmeyi öğrenmenin ne demek olduğunu bilmemekte, öğrenme stratejilerini ise kavram olarak bilmemekle birlikte bu stratejilerden bazılarını düzenli olarak olmasa da zaman zaman çalışmalarında kullanmaktadırlar. Araştırmada velilerin ve veli çocuklarının bu kavramlara ilişkin bilgileri dikkate alınarak öğrenmeyi öğrenmenin ilk aşamalarının nasıl gerçekleştirilebileceğinin desteklenmesi uygun görülmüştür. Bu bağlamda araştırmada alanyazında sıklıkla kullanılan Kolb’un (1984, akt. Güven, 2004) öğrenme stilleri ile Weinstein ve Mayer'in (1986, akt. Güven, 2004) öğrenme stratejileri sınıflamaları dikkate alınmıştır.

Araştırmanın sorun durumu alanyazındaki çalışmalar ve velilerin gerçekleştirilen odak grup görüşmesindeki görüşleri dikkate alınarak ortaya konulduktan sonra eylem araştırmasının uygulanması sürecine geçilmiştir. Uygulama süreci için Mertler ve Charles (2005)'ın (akt. Mertler, 2006) eylem araştırması döngüsü dikkate alınmıştır. Mertler ve Charles (2005)'ın önerdiği eylem araştırması süreci döngüsü planlama, uygulama, geliştirme ve yansıtma aşamalarından oluşmaktadır. Eylem araştırmasının 15.11-27.12.2018 tarihleri arasında gerçekleştirilirken, uygulama sürecinde haftalık döngü kullanılmıştır. Mertler ve Charles'ın (2005; akt. Mertler, 2006) önerdiği eylem araştırması süreci döngüsüne göre ilk eylem planı geliştirildikten (Planlama) sonra Geçerlik ve Güvenirlik Komitesi (GGK) üyelerine sunulmuş ve komitenin önerileri doğrultusunda uygulanmıştır. Uygulama her hafta perşembe günü gerçekleştirilmiştir. Uygulama esnasında araştırmacı velilerle çocuklarının öğrenmelerini onların öğrenme stillerine uygun öğrenme stratejilerini kullanarak nasıl destekleyebileceklerine ilişkin dersler yapmıştır. Yapılan dersten sonra velilerden öğrendikleri bilgileri ve uygulamaları dikkate alarak cumartesi akşamına kadar çocuklarının öğrenmelerini destekleme çalışmaları yapmalarını istemiştir. En geç cumartesi akşamı "Veli Destekleme" whatsapp grubu üzerinden yaptıkları çalışmaların neler olduğunu anlatmaları ve kendilerinin rehberliğinde çocuklarının hazırladıkları çalışma kağıtlarını paylaşmaları istenmiştir. Araştırmacı, pazar ve pazartesi günleri velilerle gerçekleştirdiği derslerin ses kayıtları ve velilerin "Veli Destekleme" whatsapp grubundan yaptıkları paylaşımlar aracılığıyla verileri toplamış ve analiz etmiştir (Uygulama). Yapılan analizler sonucunda bir sonraki haftanın ders planı geliştirilmiştir. Salı günleri verilerin analizinden elde edilen bulgular ve taslak olarak geliştirilen bir sonraki haftanın ders planı GGK toplantısında sunulmuş ve tartışılmıştır (Yansıma). GGK üyelerinin görüşleri ve önerileri doğrultusunda taslak eylem planına son şekli verilmiş (Planlama) ve bir sonraki hafta perşembe uygulanarak eylem araştırması döngüsüne devam edilmiştir. Her bir ders planının uygulanma süresi 1,5-2 saat arasında değişmektedir ve toplamda yedi haftada yaklaşı 15 saat ders yapılmıştır. Tablo I'de gerçekleştirilen gözlemlerin derslere ve ders konularına göre dağılımları verilmiştir:

Tablo I

Uygulama Sürecinde İşlenen Ders ve Ders Konularn

\begin{tabular}{lll}
\hline Tarih & Ders & Ders Konusu \\
\hline 15.11 .2018 & Türkçe & Deyimler, Atasözleri \\
\cline { 2 - 3 } & Sosyal Bilgiler & Emeviler, Endülüs Emevileri, Abbasi Devletleri \\
\hline
\end{tabular}




\begin{tabular}{lll}
\hline 22.11 .2018 & $\begin{array}{l}\text { Sosyal Bilgiler } \\
\text { Matematik }\end{array}$ & $\begin{array}{l}\text { Türklerin İslamiyet'ten önceki inanışları ve İslamiyet'i kabul edişleri } \\
\text { Tamsayların karşılaştırılması }\end{array}$ \\
\hline $\mathbf{2 9 . 1 1 . 2 0 1 8}$ & Türkçe & Zamirler \\
\hline 06.12 .2018 & Matematik & Kesir türleri ve kesirlerin karşılaştırılması \\
\hline 13.12 .2018 & Sosyal Bilgiler & $\begin{array}{l}\text { Anadolu Türk Beylikleri } \\
\text { Türkiye Selçuklu Devleti }\end{array}$ \\
\hline 20.12 .2018 & Türçe & Doğrudan ve dolaylı anlatım \\
\cline { 2 - 3 } & Matematik & Kesirli sayılarda dört işlem \\
\hline 27.12 .2018 & Sosyal Bilgiler & $\begin{array}{l}\text { Meridyen ve paralellerin özellikleri } \\
\text { Bir ülkenin ve Türkiye'nin konumu }\end{array}$ \\
\hline
\end{tabular}

Velilerle yapılan dersler, araştırmacının görev yaptığı ortaokulun Bilişim Teknolojileri ve Yazılım Odasında Perşembe günleri saat 10:30 ile 13:30/14.00 arası gerçekleştirilmiştir. Veliler ise çocukları ile yaptıkları destekleme çalışmalarını ev ortamında gerçekleştirmişlerdir.

\section{Araştırmanın Katılımcıları}

Katılımcılar araştırmacının şube rehber öğretmenliğini yürüttüğü sınıftan seçilmiştir. Bu sınıfın seçilmesinin nedenleri araştırmacının sorun durumunu bu sınıf velileri ile tespit etmiş olması ve şube rehber öğretmenliğini yaptığı sınıfın velilerini ve öğrencilerini daha iyi tanıması, araştırmaya katılımda motivasyonun ve etkin katılımın daha yüksek olacağı düşüncesidir. Araştırmacının şube rehber öğretmenliğini yaptığ araştırmanın amacından bahsedilmiş ve araştırmaya gönüllü katılmak isteyen sekiz veli ve bu velilerin çocukları araştırmanın katılımcılarını oluşturmuştur.

\section{Veri Toplama Araçları}

Eylem araştırmasının uygulanması sürecinin başında araştırmaya katılan velilerin çocuklarının öğrenme stillerini belirlemek için Kolb (1985, akt. Yazıcı, 2004) tarafından geliştirilmiş ve Yazıcı (2004) tarafından Türkçeye uyarlanmış olan "Kolb Öğrenme Stilleri Envanteri- II" kullanılmıştır. Kolb tarafından 1996 yılında ölçeğin güvenirliğine ilişkin yapılan çalışmada, ölçeğin boyutlarına ilişkin hesaplanan Cronbach Alfa katsayısının değeri .73 ile .82 arasında değişmektedir (akt. Yazıcı, 2004). Yazıcı (2004) ölçeğin uyarlama çalışmasını yaparken öncelikle Türkçe'ye çevirmiş ve yapılan tercüme iki dil uzmanı tarafından kontrol edilerek önerilen düzeltmeler yapılmıştır. Yazıcı (2004) ölçeğin güvenirlik hesaplamaları için ilköğretim öğrencilerinden oluşan iki farklı örneklemden veri toplamıştır. I. uygulamada ölçeğin alt boyutları için hesaplanan güvenirlik katsayıları .38 ile .67 arasında; II. uygulamada ise .19 ile .69 arasında değişmiştir. Ayrıca I. ve II. uygulamalar için güvenirlik katsayısı olarak eşdeğer yarılar güvenirliğini de hesaplamış; bu değerler ölçeğin farklı evreleri için .23 ile .60 arasında değişmiştir. Yazıcı (2004) hesaplanan güvenirlik katsayıları düşük olmasına rağmen ölçek ile ilgili daha önce yapılmış güvenirlik analizi çalışmalarını da göz önüne alarak ölçeğin orta güvenirlikte bir ölçek olarak kabul edilebileceğini belirtmiştir. Ölçeğin kullanımı için gerekli izinler alınmıştır. Velilerin öğrenmeyi öğrenme, öğrenme stili ve öğrenme stratejileri kavramlarına ilişkin önbilgilerini belirlemek için onlarla bir defaya mahsus bir odak grup görüşmesi gerçekleştirilmiştir.

Eylem planlarının uygulanması sürecinde velilerin çocuklarıyla gerçekleştirdikleri destekleme çalışmalarında onların öğrenme stillerine uygun öğrenme stratejilerini kullanma becerilerindeki gelişimi belirlemek için ders ses kayıtları, alan notları ve araştırmacı günlüğü, "Veli Desteği” whatsapp grubu, öğrenci çalışma kağıtları ve geçerlik-güvenirlik komitesi toplantı kayıtları kullanılmıştır. Ses kayıtları, araştırmacı tarafından haftalık olarak her ders için gerçekleştirilmiştir. Ses kayıtları yanında araştırmacı dışında bir uzman, katılımcı gözlemci olarak bazı haftalarda derslere katılmış ve alan notları tutmuştur. Araştırmacı eylem planlarının uygulandığı her dersin başında ve sonunda araştırmacı günlüğü tutmuştur. "Veli Desteği" whatsapp grubu velilerle gerçekleştirilen derslerden sonra velilerin çocukları ile yaptıkları destekleme çalışmalarını anlattıkları, o haftanın uygulamasını gerçekleştirirken yaşadıkları sorunlar var ise ifade ettikleri ve kendi rehberliklerinde çocuklarının yaptıkları çalışma kağıtlarını paylaştıkları sosyal ağ platformudur. Öğrenci çalışma kağıtları, çocukların eylem planlarının uygulandığı derslerde işlenen ders konularına yönelik araştırmaya katılan velilerinin rehberliğinde öğrenme stillerine uygun öğrenme stratejilerini kullanarak 
hazırladıkları çalışma kağıtlarıdır. Uygulama sürecinin başında bir geçerlik ve güvenirlik komitesi oluşturulmuştur. Eylem planları uygulanırken karşılaşılan sorunlar, bu sorunların nasıl çözülebileceği, eylem planlarının geliştirilmesi ve uygunluğu konularında geçerlik ve güvenirlik komitesi üyeleri ile uygulamanın gerçekleştiği süreç boyunca haftalık toplantılar gerçekleştirilmiş; komite üyelerinin görüş ve önerilerinden yararlanılmıştır. Alınan bu kararlar araştırmacı tarafından "Geçerlik ve Güvenirlik Komitesi Toplantı Kayıtları"na kaydedilmiş, araştırmacı tarafından bir sonraki haftanın eylem planlarına yansıtılmıştır.

Eylem araştırmasının uygulanması sürecinin sonunda velilerin ve çocukların görüşlerini belirlemek için onlarla yarı yapılandırılmış görüşme formu ile görüşmeler gerçekleştirilmiştir. Bu görüşmeler ile onların uygulama sürecinde yapılan etkinliklerin etkililiğine ilişkin görüşleri alınmıştır.

\section{Verilerin Analizi}

Eylem araştırmasının uygulanması süreci içerisinde ve sonunda toplanan verilerin analizinde betimsel analiz kullanılmıştır. Uygulama sürecindeki sesli ders kayıtları, alan notları, öğrenci çalışma kağıtları ve "Veli Desteği" whatsapp grubu kayıtlarının analizinde kullanılan mikro analiz formları Kolb'un her bir öğrenme stiline uygun olarak alanyazına dayalı belirlenen öğrenme stratejilerine göre hazırlanmıştır. Bir sonraki haftanın eylem planının hangi becerilere yönelik hazırlanacağının belirlenmesi için GGK üyelerinin kararları doğrultusunda uygulama sürecinde mikro düzeyde betimsel analiz yapılması uygun görülmüştür. Verilerin analizinde velilerin açıklamaları, ifadeleri ve/veya öğrenci çalışma kağıtlarındaki uygulamalar analiz birimi olarak kabul edilmiştir. Ses kayıtları, alan notları, öğrenci çalışma kağıtları ve whatsapp gurubu kayıtları üzerinde ilgili veliye göre kodlamalar gerçekleştirilmiştir. Analizlerde velilerin stratejileri ilgili haftada ne kadar kullandığı değil; kullanıp/kullanmama durumu dikkate alınmıştır. Analiz formlarına kodlanan veriler gerekli yerlerde doğrudan alıntılar ile desteklenmiştir. GGK toplantılarının kayıtları araştırma bulgularının yorumlanmasında ve desteklenmesinde kullanılmıştır.

Uygulama sonrası velilerle ve bu velilerin çocukları ile gerçekleştirilen görüşmeler için hazırlanan kodlama anahtarı farklı olmakla birlikte analiz ve yorumlama süreçleri benzerlik göstermektedir. Veliler ve çocuklarıyla yapılan görüşmelerin analizinde betimsel analiz kullanılmıştır. Öncelikle kodlama için tematik çerçeve oluşturulmuştur. Erişilen tema ve kodlar metin içerisinden çeşitli alıntılarla desteklenmiştir. Tanımlanan bulgular araştırma soruları ile ilişkilendirilerek açıklanmıştır.

\section{Geçerlik ve Güvenirlik Çalışmaları}

Araştırmanın her aşamasında yapılan çalışmalar GGK ile paylaşılmıştır. Araştırmada bu komitede yer alan uzmanlardan biri doktora tezi çalışmasını eylem araştırması yöntemi ile yapmış; eylem araştırmasına dayalı bir çok tez danışmanlığı yapmış bilgisayar ve öğretim teknolojileri alanında öğretim elemanı; diğeri ise farklı eylem araştırmalarının güvenirlik çalışmalarında bulunmuş, doktora tez çalışmasını öğrenme stilleri ve öğrenme stratejileri üzerine gerçekleştirmiş eğitim programları ve öğretim alanında öğretim elemanı olarak görev yapmaktadır. Araştırmacının yaptığı tüm analizler her hafta GGK'de komite uzmanlarına sunulmuştur. Araştırmacı eylem planlarına dayalı haftalık derslerini gerçekleştirirken velilerin video kaydını istememeleri nedeniyle ses kayıtları yapılmıştır. Bu ses kayıtları her hafta eylem planları ile birlikte GGK üyeleri ile paylaşılmış; bununla birlikte geçerliği ve güvenirliği artırmak için belirli haftalarda araştırmacı ile birlikte bir katılımcı gözlemci de derslere katılarak alan notları tutmuştur. Araştırmada veri çeşitlemesi yapılmıştır. Uygulama sürecinde alan notları, çalışma kağıtları, ses kayıtları, araştırmacı günlüğü, whatsapp veli destek grubu; uygulama sürecinin sonunda ise öğrencilerle ve velilerle görüşmeler gerçekleştirilerek araştırmada detaylı ve derinlemesine bulgular elde edilmiştir.

Araştırmada elde edilen bulguların güvenirliğinin sağlanmasında uygulama sürecinde ve sonunda elde edilen nitel verilerin analizinde Miles ve Hubarman'ın (1994) güvenirlik hesaplamalarını dikkate alınmıştır. Bu hesaplama doğrultusunda kodlayıcılar arası görüş birliği ve görüş ayrılıkları sayısı belirlemiş ve güvenirlik oranları hesaplanmıştır. Alan notları, çalışma kağıtları ve ders ses kayıtlarının rastgele seçilen \% 30'luk bölümünün araştırmacı dışında bir uzman araştırmacı tarafından da kendisine verilen betimsel mikro analiz formu üzerinden analiz etmesi sağlanmıştır. Uygulama sürecinde yapılan bu güvenirlik analizlerinin 
sonuçları, her biri için \% 80'in üzerinde olmuştur. Uygulama süresinin sonunda veli ve öğrenci görüşme ses kayıtlarının analizinde de \% 30'luk bir kesit araştırmacı dışında bir uzmana kodlama listesi ile birlikte verilmiş ve yeniden kodlaması istenmiştir. Güvenirlik hesaplamasından elde edilen sonuç \% 86'dır.

\section{Bulgular}

\section{Öğrenme Stiline Dayalı Veli Destekleme Çalışmasının Tasarımlanması}

Araştırmacı, velilerin öğrenme ihtiyaçları doğrultusunda eylem planlarının uygulanması öncesini kapsayan birinci aşamada öncelikle velilere öğrenmeyi etkileyen faktörler, öğrenmeyi öğrenme ve aile katılımı ile ilgili bilgilendirici sunum yapmıştır. Velilerin çocuklarına Kolb öğrenme stilleri envanterini dağıtılarak onların öğrenme stilleri belirlenmiştir. Tablo II'de araştırmaya katılan velilerin çocuklarının öğrenme stilleri görülmektedir.

Tablo II

Velilerin Çocuklarının Öğrenme Stilleri

\begin{tabular}{cccc}
\hline Veli & Çocuğunun öğrenme stili & Veli & Çocuğunun öğrenme stili \\
\hline S. C. & Ayırt edici & G. Ç. & Yerleştiren \\
H. U. & Ayırt edici & E. Y. & Değiştiren \\
R.Y. & Ayırt edici & C. T. & Ayırt edici \\
F. A. & Ayırt edici & E. P. & Özümleyici \\
\hline
\end{tabular}

Tablo II'de görüldüğ̈̈ gibi araştırmaya katılan sekiz velinin beş tanesinin çocuğunun öğrenme stili ayırt edicidir. Diğer velilerin çocuklarından biri yerleştiren, biri özümleyici, biri ise değiştiren öğrenme stiline sahiptir. Öğrenme stilleri belirlendikten sonra velilerle çocuklarının hangi öğrenme stiline sahip olduğu paylaşılmış ve bir sonraki derse kadar olan bir haftalık süreçte onları sahip oldukları öğrenme stilinin özelliklerine göre evde gözlemlemeleri istenmiştir. Bir sonraki hafta yapılan derste çocuklarının öğrenme stillerine uygun öğrenme stratejileri ve bu öğrenme stratejilerine uygun kullanabilecekleri teknikler hakkında kısa bilgiler verilmiştir. Eylem araştırması uygulamasından önceki son hafta ise destekleme çalışmalarının hangi derslere yönelik olacağına ve ders sürelerinin ne kadar olacağına velilerle birlikte karar verilmiştir. Veli destekleme çalışmasının konuları uygulama sürecinin başında belirlenebileceği gibi süreç içerisinde de ihtiyaca göre yeniden belirlenebilmiştir. Örneğin, bir veli uygulama sürecinin son haftalarında sosyal ilgiler dersine yönelik sınava hazırlık çalışmalarının yapılıp yapılamayacağını sormuştur. Ardından oybirliği ile ilgili haftada sosyal bilgiler sınavına yönelik haftalık ders yapılmıştır. Eylem planlarının uygulanması sürecinde derslerde araştırmacı tarafından gerçekleştirilen ders planları ufak değişikliklerle velilere uyarlanarak fotokopi olarak onlara dağıtılmıştır. Oluşturulan "Veli Desteği" grubu, araştırmacının dijital sunular gibi bazı materyalleri paylaşmasında, velilerin öğrenci çalışmalarını göndermelerinde, yaptıkları destekleme çalışmalarıyla ilgili bilgi vermelerinde, karşılaştıkları sorunları kısa sürede paylaşabilmelerinde ve onlara esnek bir öğrenme ortamı sağlamada etkili olmuştur. Böylece velilerin katılımlarının ve çalışmaları gerçekleştirmedeki motivasyonlarının yüksek tutulması sağlanmıştır.

Araştırmacı her hafta eylem planlarını uygularken ders planında neler olduğunu kısaca açıklamış ve o haftanın destekleme çalışması konusunu dikkate alarak stratejilerin kullanımına yönelik örnekler yapmıştır. Araştırmacı derste öğrenme stillerine uygun öğrenme stratejilerini anlatırken aynı zamanda ilgili dersin ders konusunu da anlatmıştır. Velilerin ders konusunu anladıklarında daha etkili destekleme çalışmaları yaptıkları görülmüştür.

Destekleme çalışmasının gerçekleştirilmesi sırasında velilerin derse katılımının sağlanması ve motivasyonlarının yüksek tutulması önemli olmaktadır. Araştırmacı, konu anlatımı sırasında zaman zaman hem dersin veliler tarafından anlaşılırlığını kontrol etmek hem de velilerin derse aktif katılımını sağlamak amacıyla onlara sorular sormuştur:

\footnotetext{
A: Şimdi 7 bölü 2 çarp 3 bölü 4 evet. Kuralları hatırlayalım neydi? Kitapları hatırlayın kütüphaneden. (Araştırmacı kuralın hatırlanmasında kullandığı bellek destekleyiciyi hatırlatmaktadır.)

A.P: Üst ile üst alt ile alt çarpılacak.

A: Evet aynen öyle.

E.Y: Sadeleştirme var mı diye bakıyoruz ama yok.
} 
A: Evet doğru o da önemli daha kolay çarpma yapabilmemiz için.

Araştırmacı uygun olduğunda velilerin derse karşı ilgilerini ve motivasyonlarını yüksek tutmayı sağlayacak ifadeler kullanmıştır: “Güzel çahışıorsunuz çabuk anlıyorsunuz gerçekten. Hızlısınız yani imkanınız olsaymış daha çok okuyabilirmiş- siniz, kesin üniversiteye gidermişsiniz... Tebrikler o kadar hızlısınız ki daha benim soru çalışması vermediğim konulardan bile destekleme çalışması yapmışsını.." (Araştırmacı).

\section{Velilerin Destekleme Çalışmalarında Çocuklarının Öğrenme Stillerine Uygun Öğrenme Stratejilerini Kullanma Durumları}

\section{Velilerin anlamlandırma stratejilerini kullanma durumlarının geliştirilmesi.}

Tablo III'te eylem planlarının uygulanması sürecinde velilerin çocuklarının öğrenmelerini desteklemede kullandıkları anlamlandırma stratejilerinin haftalık dağılımı gösterilmiştir. Tüm öğrenme stillerinde kullanımı uygun olan bellek destekleyiciler velilerin çocuklarının öğrenmelerini desteklerken kullanmakta en fazla zorlandığı anlamlandırma stratejisi olmuştur. Tablo III'te görüldüğü gibi velilerin tamamı ilk hafta anlatılan bellek destekleyicileri, çocukları ile evde gerçekleştirdikleri destekleme çalışmalarında kullanamadıklarını ifade etmişlerdir. Bazı velilerin bellek destekleyicileri kullanamamalarının nedenlerinden biri onlara mantıklı gelmemesi olmuştur:

A: Burada devletlerin kuruluş tarihleri ile baş harflerini ilişkilendirebilirsiniz. Ama burada devletlerin baş harflerinin alfabedeki yeri ile kuruluş tarihleri arasında ters yönde bir ilişki var.

C.T: Hocam bu bana çok mantıklı gelmedi yani şimdi doğru orantılı olsaydı çocukların akılda kalıcılı̆̆ı kolay olabilirdi ancak ters ilişki olduğu için çocuklar karıştırabilir yani. Ters miydi düz müydü diye.

Araştırmacı örneklerin velilere mantıklı gelmemesi durumunu dikkate alarak sonraki haftalarda alternatif örnekler sunmuştur. Araştırmacı ikinci hafta GGK toplantılarında alınan kararlar doğrultusunda bellek destekleyicilere yönelik daha fazla örnek göstermeye ve nasıl oluşturulduklarını açıklamaya devam etmiştir. 3. haftadan itibaren bazı velilerin ders anlatımından sonra evde çocuklarıla uyguladıkları destekleme çalışmaları sırasında hazırladıkları çalışma kağıtlarında bellek destekleyicilere örnekler verdikleri görülmüştür. Bazı veliler de derslerde anlatılan öğrenme konusunu dikkate alarak kendi bellek destekleyicilerini oluşturmuşlardır: "Çaka bey denizcilikte iyi ya. Çaka-çapa (denizde demir atma) oradan bir bellek destekleyici oluştururum." (C.T).

Neden-sonuç ilişkisi kurma stratejisinin ise özellikle ayırt edici, özümleyici ve değiştiren öğrenme stillerine sahip çocukların öğrenmelerinde etkili olduğu söylenebilir. Velilerin çocukları ile birlikte gerçekleştirdikleri destekleme çalışmalarında hazırladıkları çalışma kağıtları incelendiğinde 5. haftanın sonunda hemen hemen tamamında neden-sonuç ilişkisi oluşturma stratejisinin kullanıldığı görülmüştür. Neden-sonuç ilişkisini nasıl kullandıklarına dair bir velinin açıklaması şu şekildedir: "Ben paydaları farklı olan kesirlerin neden toplanamadığını şema ile gösterdim..." (R.Y). 
Tablo III

Gülten Feryal GÜNDÜZ

Velilerin Çocuklarının Öğrenmelerini Desteklemede Kullandıkları Anlamlandırma Stratejilerinin Haftalara Göre Dağılımı*

\begin{tabular}{|c|c|c|c|c|c|c|c|c|c|c|c|}
\hline & \multicolumn{4}{|c|}{ 1.HAFTA } & \multicolumn{7}{|l|}{ 2.HAFTA } \\
\hline & $\begin{array}{l}\text { Soru } \\
\text { Sorma }\end{array}$ & $\begin{array}{l}\text { Hikayeler / } \\
\text { Okuma } \\
\text { Etkinlikleri }\end{array}$ & $\begin{array}{c}\text { Bellek } \\
\text { Destekleyiciler }\end{array}$ & $\begin{array}{l}\text { Şekiller- } \\
\text { Görseller }\end{array}$ & $\begin{array}{l}\text { Soru } \\
\text { Sorma }\end{array}$ & $\begin{array}{l}\text { Hikayeler / } \\
\text { Okuma } \\
\text { Etkinlikleri }\end{array}$ & $\begin{array}{c}\text { Bellek } \\
\text { Destekleyiciler }\end{array}$ & $\begin{array}{l}\text { Şekiller- } \\
\text { Görseller }\end{array}$ & Canlandırma & $\begin{array}{l}\text { Somut } \\
\text { Örnekler }\end{array}$ & $\begin{array}{l}\text { Dijital } \\
\text { Sunular }\end{array}$ \\
\hline S.Ç (A) & - & $x$ & - & - & $x$ & - & $X$ & $x$ & - & $x$ & - \\
\hline R.Y (A) & - & - & - & $x$ & - & - & - & - & - & & - \\
\hline F.A (A) & - & $x$ & - & $x$ & - & - & - & - & - & $x$ & - \\
\hline G.Ç (Y) & - & - & -- & $x$ & $x$ & - & $x$ & $x$ & $x$ & $x$ & $x$ \\
\hline E.Y (D) & - & $x$ & - & $x$ & $x$ & - & - & $x$ & - & - & - \\
\hline \multirow[t]{3}{*}{ E.P (Ö) } & - & $x$ & - & - & - & - & - & - & - & $x$ & - \\
\hline & \multicolumn{11}{|c|}{ 3.HAFTA } \\
\hline & $\begin{array}{l}\text { Soru } \\
\text { Sorma }\end{array}$ & $\begin{array}{l}\text { Hikayeler / } \\
\text { Okuma } \\
\text { Etkinlikleri }\end{array}$ & $\begin{array}{c}\text { Bellek } \\
\text { Destekleyici }\end{array}$ & $\begin{array}{l}\text { Şekiller - } \\
\text { Görseller }\end{array}$ & $\begin{array}{c}\text { Somut } \\
\text { Örnekler }\end{array}$ & $\begin{array}{l}\text { Dijital } \\
\text { Sunular }\end{array}$ & Tümevarım & \multicolumn{3}{|c|}{ Canlandirma } & \\
\hline S.Ç (A) & $x$ & $x$ & $\bar{X}$ & $x$ & $X$ & $x$ & $\bar{X}$ & - & \multicolumn{2}{|c|}{$x$} & \\
\hline H.Ü (A) & $x$ & - & $x$ & $x$ & $x$ & $x$ & - & - & \multicolumn{2}{|l|}{-} & \\
\hline R.Y (A) & $x$ & - & - & $x$ & $x$ & - & - & - & \multicolumn{2}{|l|}{ - } & \\
\hline F.A (A) & $x$ & $x$ & $x$ & $x$ & $x$ & $x$ & - & - & \multicolumn{2}{|l|}{$x$} & \\
\hline E.Y (D) & $x$ & $x$ & - & $x$ & $x$ & $x$ & - & - & \multicolumn{2}{|l|}{ - } & \\
\hline C.T (A) & - & - & - & $x$ & $x$ & - & - & - & \multicolumn{2}{|l|}{ - } & \\
\hline E.P (Ö) & - & $x$ & - & $x$ & $x$ & - & - & - & \multicolumn{2}{|c|}{$x$} & \\
\hline
\end{tabular}

*Araştırma kapsamındaki öğrenme stratejilerinin çok fazla olması nedeni ile tabloda haftalar altında sadece o hafta anlatılan öğrenme stratejileri gösterilmiştir.

**Velilerin (Katılımcıların) isimlerinin yanında parantez içinde çocuklarının öğrenme stilleri gösterilmiştir.

*** Tabloda velilerin öğrenme stratejilerini kullanma sıklıkları değil kullanıp/kullanmama durumları gösterilmiştir. (X: kullandı -: kullanmadı)

***** Bu tablo (Tablo 3) için yapılan bu açıklamaların tümü velilerin destekleme çalışmalarında çocuklarının öğrenme stillerine uygun öğrenme stratejilerini kullanma durumlarına ilişkin verilen tüm bulgu tabloları (Tablo 4-5, 6, 7) için geçerlidir. 
Tablo III devamı

Velilerin Çocuklarııın Ö̆grenmelerini Desteklemede Kullandıkları Anlamlandırma Stratejilerinin Haftalara Göre Dağılımı

\begin{tabular}{|c|c|c|c|c|c|c|c|c|}
\hline & \multicolumn{8}{|c|}{ 4.HAFTA } \\
\hline & Bellek Destekleyiciler & Soru sorma & $\begin{array}{l}\text { Hikayeler / } \\
\text { Okuma } \\
\text { etkinlikleri }\end{array}$ & $\begin{array}{l}\text { Neden-sonuç } \\
\text { ilişkisi }\end{array}$ & Dijital sunular & Tümevarım & Tümdengelim & Canlandırma \\
\hline S.Ç (A) & $x$ & $x$ & $\mathrm{X}$ & $x$ & $x$ & $x$ & - & $x$ \\
\hline H.Ü (A) & $x$ & $x$ & - & $x$ & $x$ & - & $x$ & $x$ \\
\hline R.Y (A) & $X$ & $x$ & - & $X$ & $X$ & - & - & - \\
\hline F.A (A) & $x$ & $X$ & - & $x$ & $X$ & - & $X$ & $\mathrm{X}$ \\
\hline G.Ç (Y) & $X$ & $x$ & - & $x$ & $x$ & - & $x$ & $x$ \\
\hline E.Y (D) & - & $x$ & $x$ & $x$ & $x$ & - & $x$ & - \\
\hline C.T (A) & $X$ & $x$ & $X$ & $x$ & $x$ & - & - & - \\
\hline \multirow[t]{3}{*}{ E.P $(\ddot{O})$} & - & $x$ & $x$ & $x$ & $x$ & - & - & $x$ \\
\hline & \multicolumn{4}{|c|}{ 5.HAFTA } & \multicolumn{4}{|c|}{ 6.HAFTA } \\
\hline & Bellek Destekleyiciler & Okuma çalışmaları & Tümevarım & Tümdengelim & $\begin{array}{c}\text { Bellek } \\
\text { destekleyiciler }\end{array}$ & Tümdengelim & Tümevarım & \\
\hline S.Ç (A) & $X$ & $x$ & $X$ & - & $x$ & - & $x$ & \\
\hline H.Ü (A) & $x$ & $x$ & $x$ & - & $x$ & - & $x$ & \\
\hline R.Y (A) & $x$ & $X$ & - & $x$ & $X$ & - & $X$ & \\
\hline F.A (A) & $x$ & $x$ & - & $x$ & $x$ & - & $x$ & \\
\hline G.Ç $(\mathrm{Y})$ & $X$ & $x$ & - & - & $x$ & $X$ & - & \\
\hline E.Y (D) & - & $x$ & - & $x$ & $x$ & $x$ & - & \\
\hline C.T (A) & - & - & $x$ & $x$ & - & $X$ & - & \\
\hline E.P (Ö) & - & $x$ & $x$ & $x$ & - & - & $x$ & \\
\hline
\end{tabular}


Araştırmacı velilere tüm öğrenme stillerinde kullanabilecekleri bir başka anlamlandırma stratejisi olan dijital sunuları destekleme çalışmalarında nasıl kullanılabileceklerini ve derslere ilişkin dijital sunular seçilirken nelere dikkat etmeleri gerektiğini anlatmış; plan kapsamında hazırlamış olduğu dijital sunuları velilerle paylaşmıştır. İkinci hafta yalnızca bir veli ilgili videoyu çocuğuna gösterdiğini söylemiştir. İkinci haftanın sonunda bir komite uzmanı dijital sunuların kullanımının artırılması amacıyla video oluşturulup yayınlanmasını ve grupta dijital sunuların kullanımında sorun yaşayanların desteklenmesini önermiştir.

Araştırmacı uzmanın bu görüşü doğrultusunda internetten öğrenme konusuna uygun bir dijital sununun nasıl bulunacağını ve kullanılacağını ders içerisinde uygulamalı olarak anlatmış; velilere uygulama yaptırmış ve sorun yaşayan veliler whatsapp grubu üzerinden desteklenmiştir. Dördüncü haftadan itibaren tüm velilerin araştırmacının derslerde anlattığı dijital sunuları evde çocuklarıyla destekleme çalışmalarında kullandıkları görülmüştür.

Soru çalışmaları tüm öğrenme stillerinde önemli olmakla birlikte alanyazına göre özellikle ayırt edici, değiştiren ve yerleştiren öğrenme stillerine sahip çocukların öğrenmelerinde daha etkili olmaktadır. Soru çalışmalarının yapılmaya başlandığı 2 . haftada dört veli, evde çocukları ile destekleme çalışmalarını yaparken kendilerinin öğrenme konusu ile ilgili çocuklarına soru sorduklarını ve soru-cevap çalışması yaptıklarını; bazı veliler ise çocuklarının da onlara konu ile ilgili soru sorduklarını belirtmişlerdir. 4. haftadan itibaren ise tüm veliler kullanmaya başlamışlardır. Bazı veliler soru çalışmaları yaptıklarını sözlü olarak ifade ederken; bazı veliler yaptıkları soru çalışmalarını destekleme çalışmaları esnasında hazırladıkları çalışma kağıtlarında da göstermişlerdir. Soru çalışmalarına ilişkin iki veli ve çocukları tarafından gerçekleştirilen destekleme çalışmalarında hazırlanan çalışma kağıtları Şekil 1'de sunulmuştur.
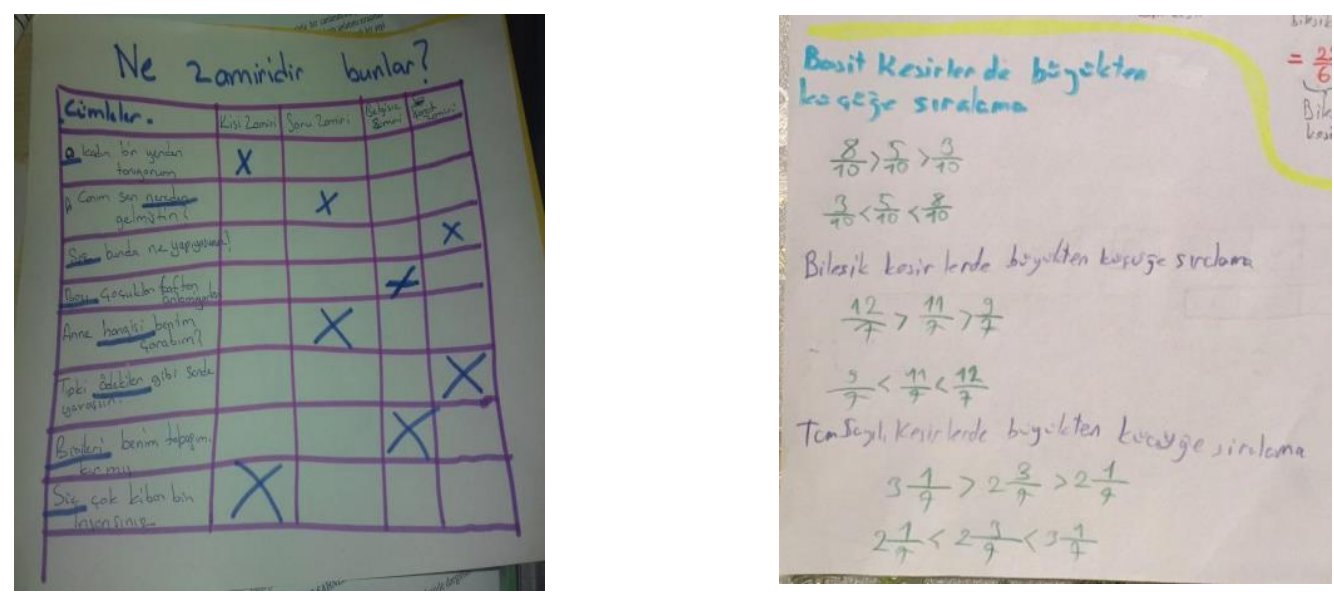

Şekil 1. Soru sorma stratejilerinin kullanıldığını gösteren çalışma kağıtlarından örnekler

Hikaye ve okuma etkinliklerinden özümleyici ve değiştiren öğrenme stiline sahip çocukların daha fazla hoşlandıkları söylenebilir. Bununla birlikte S. Ç.'nin kızı ayırt edici öğrenme stiline sahip olmasına rağmen kızının hikaye çalışmalarından hoşlandığını belirtmiştir. S.Ç. bu durumu kızının okuma çalışmalarını sevmesi ile ilişkilendirmiştir. Alanyazına göre her ne kadar bazı öğrenme stillerine sahip kişiler okumaya dayalı çalışmalardan daha fazla hoşlansalar ve buna bağlı olarak öğrenmelerinde daha fazla tercih ediyor olsalar bile unutulmaması gereken önemli bir nokta çocukların bazı becerileri temel düzeyde kullanıyor olmaları gerekmektedir. Örneğin; okuma becerileri tüm öğrencilerin sahip olması gereken becerilerdir. Bu durum velilere de ifade edilmiş ve araştırmacı okuma parçalarından hoşlanmayan çocuklar için velilere zaman zaman önerilerde bulunmuştur. Alanyazına göre canlandırma ve rol alma stratejilerinin ayırt edici ve yerleştiren öğrenme stillerine sahip çocuklarda daha etkili kullanıldığı söylenebilir. Birinci hafta velilerden sadece bir tanesi çocuğu ile canlandırma çalışması yapmıştır. 3. hafta araştırmacı ders planına bir tiyatro sahnesi eklemiş ve öğrenme stillerine uygun olarak bazı çocukların bu tiyatro sahnesine yönelik canlandırma çalışmaları; bazılarının ise okuma çalışmaları yapabilecekleri söylenmiştir. Çocukları ayırt edici ve yerleştiren öğrenme stiline sahip dört veli tiyatro sahnesini evde oynadıklarını söylemişlerdir. Canlandırma çalışması yapan bir 
çocuk ise özümleyici öğrenme stiline sahiptir. 4. hafta beş veli derste anlatılan farklı konulara yönelik canlandırma çalışmaları yaptıklarını ifade etmişlerdir.

3. haftadan itibaren tümdengelim-tümevarım öğrenme yaklaşımları üzerinde durulmuştur. Öğrenme stillerinin özelliklerine göre ayırt edici ve özümleyici öğrenme stillerinde tümevarım; değiştiren ve yerleştiren öğrenme stillerinde ise tümdengelim öğrenme yaklaşımı daha etkili olmaktadır. Bu öğrenme yaklaşımlarını 4. haftaya kadar sadece iki veli kullanmış; bu haftadan itibaren bu stratejileri kullanan veli sayısı artmış, ancak bunları öğrenme stillerine uygun olarak gerçekleştirememişlerdir. Araştırmacı bunun nedeninin ne olabileceğini velilere sormuştur. Velilerin yarısına yakını aşağıda örnek olarak sunulan veli görüşüne yakın ifadelerde bulunmuşlardır. Bir velinin ifadesi şu şekilde olmuştur: "Aaa! Ben yine dikkat etmeyi unuttum. Yani şimdi bir de sanırım çocukların defterlerinden de etkileniyoruz. Hani öğretmenlerinin çoğu defterlerine baktı̆̆ımda önce tanımı vermişler sonra örnekleri. Sanırım o da yanıltıyor beni." (F.A).

Velilerin buna benzer açıklamaları doğrultusunda tümdengelim stratejisinin tercih edilmesinin nedeninin daha kolay olması, ders defterlerinde ve kitaplarında daha fazla kullanılması ve hem velilerin hem de öğrencilerin kullanımına daha alışık oldukları bir strateji olması olduğu söylenebilir. Son iki hafta velilerin çoğunluğunun çocuklarının öğrenme stillerine uygun öğrenme yaklaşımlarını kullandıkları görülmüştür. Velilerin tümdengelim ve tümevarımı kullandıklarını ifade ettikleri destekleme çalışmalarından bazıları Şekil 2' de gösterilmiştir.
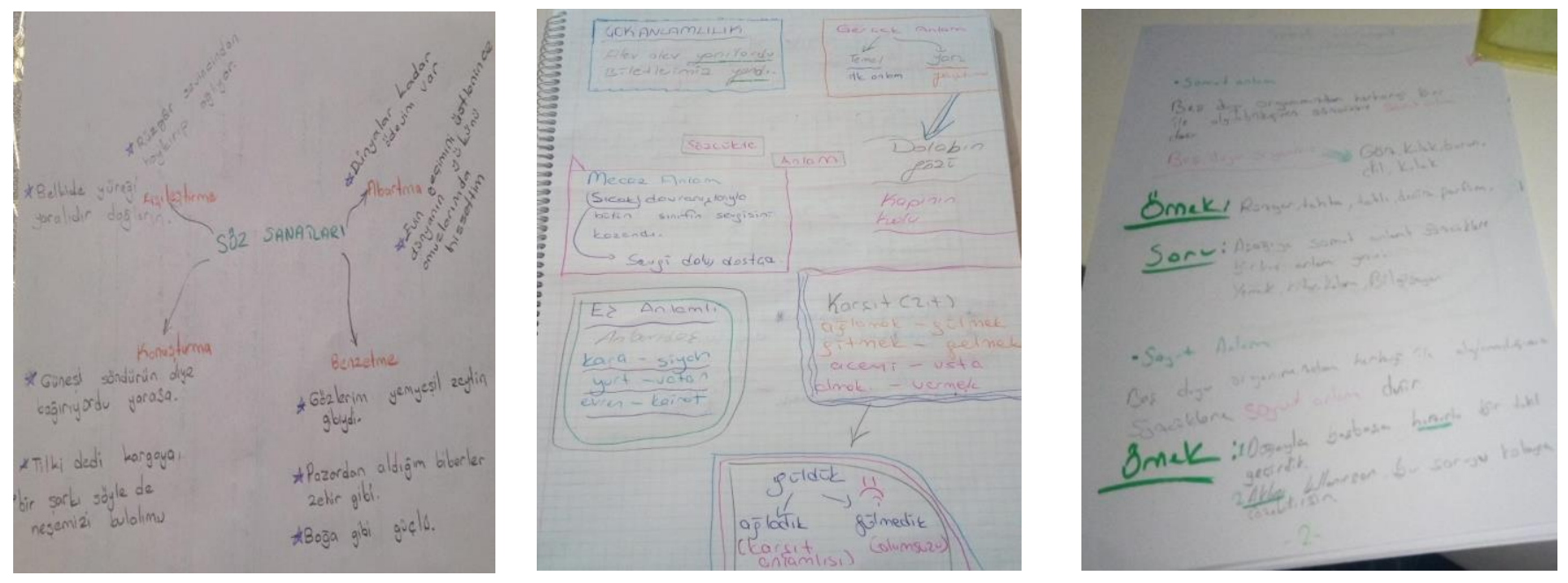

Şekil 2. Tümdengelim ve tümevarım stratejilerinin kullanıldığını gösteren çalışma kağıtlarından örnekler

Şekil 2'deki çalışmaların ilk iki tanesinde veliler öncelikle kavramlar ile ilgili örnekleri verdiklerini ve bu örneklerden yola çıkarak çocuklarından her bir kavramın ne anlama geldiğini tanımlamalarını istediklerini söylemişlerdir. Son çalışmada ise veli öncelikle soyut ve somut kavramların tanımlarını yaptığını ve sonrasında bu kavramlara ilişkin örnekler verdiğini belirtmiştir. Araştırmacı 6. hafta tümdengelim ve tümevarımı anlatmadan önce velilere ne demek olduklarını sormuştur. Velilerin cevaplarından bu hafta tümevarım ve tümdengelimin ne demek olduğunun çoğunluğu tarafından anlaşıldıkları görülmüştür.

Eylem planları süresince veliler tarafından en kolay anlaşılan ve en fazla kullanılan anlamlandırma stratejileri somut örnekler olmuştur. Tüm öğrenme stillerine sahip çocukların öğrenmesinde önemli olan somut örnekler araştırma süresince tüm veliler tarafından kullanılmıştır. Velilerin çocuklarının öğrenmelerin desteklerken kullandıkları somut örneklere ilişkin görüşlerinden bazıları şunlardır: "Belgisiz zamiri anlatırken dışarıdan duyduğum bir sesten örnek verdim ben." (H.Ü). "Kızımın doğum günü vardı ben doğum günü pastasından kesirli ifadeler oluşturdum ona. Öyle örneklendirdim yani hoşuna gitti." (A.P).

\section{Velilerin örgütleme stratejilerini kullanma durumlarının geliştirilmesi}

Tablo IV'te eylem araştırmasının uygulama sürecinde velilerin çocuklarının öğrenmelerini desteklemede 
kullandıkları örgütleme stratejilerinin haftalara göre dağılımı verilmiştir. Elde edilen bulgular tablolaştırma stratejisinin diğer örgütleme stratejilerine göre daha kolay kavranan ve kullanılan strateji olduğunu göstermektedir. Veliler bu stratejiyi daha fazla kullanmalarını çocuklarının bazı ders defterlerinde görmeleri ile de ilişkilendirmişlerdir.

Tablo IV'te görüldüğü gibi 2. haftadan itibaren farklı öğrenme stillerine sahip tüm çocukların öğrenmelerini desteklemede tablo ve çizelgelerin tüm veliler tarafından kullanıldığı görülmüştür. Bu stratejilerin kullanımının gözlemlendiği veli destekleme çalışmalarından bazıları Şekil 3'te gösterilmiştir:
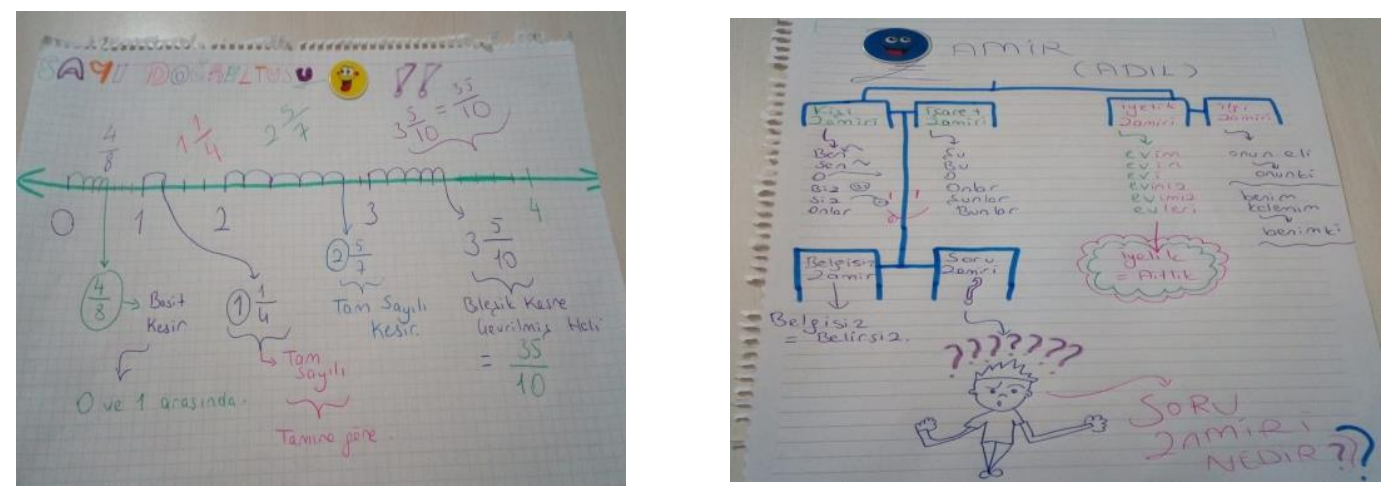

Şekil 3. Çizelgelerin kullanıldığını gösteren çalışma kâğıtlarından örnekler

Veliler ilk hafta anlatılan ve tüm öğrenme stillerinde kullanılabilecek zihin haritalarını destekleme çalışmalarında kullanmakta zorlanmışlar. Ancak Tablo IV'te görüldüğü gibi üçüncü haftadan itibaren araştırmacının zihin haritalarına ilişkin örnekleri artırması ile velilerin tümü kullanmaya başlamışlardır. Bunun en önemli nedenlerinin ikinci haftadan itibaren araştırmacının ders planında destekleme çalışması yapılan konu ile bağlantılı daha fazla kavram haritasına yer vermesi ve kavram haritalarını konu ile bağlantılı olarak sunmadan önce GGK üyelerinin önerileri doğrultusunda kavram haritalarına ilişkin ne olduğu, nasıl oluşturulduğu ve ne amaçla kullanıldığına dair daha detaylı bilgi vermesi olduğu söylenebilir.

Örgütleme stratejilerinden olan ana hatları çıkarmanın özümleyici, dönüştürücü ve yerleştiren öğrenme stillerine sahip çocukların öğrenmelerinde daha etkili olduğu söylenebilir. Araştırmacı velilere destekleme çalışmalarında öğrenme konusu ile ilgili ders kitaplarından ya da farklı kitaplardan önemli yerlerin altını çizerek ana hatları çıkarabileceklerini söylemiştir. Çocuğu değiştiren öğrenme stiline sahip bir veli dışında, tüm veliler ana hatları çıkarma stratejisini destekleme çalışmalarında etkili olarak kullanmışlardır.

Velilerin destekleme çalışmalarında kullanmakta en fazla zorlandıkları örgütleme stratejisi ayırt edici, yerleştiren ve özümleyici öğrenme stillerine sahip çocukların öğrenmelerinde daha etkili olduğu söylenebilecek kümelendirme stratejileri olmuştur. Kümelendirme stratejisi ilk haftalarda velilerin büyük bir çoğunluğu tarafından kullanılmamıştır. Araştırmacı derste velilere kümelendirme stratejisini neden kullanmadıklarını da sormuştur. Bazı veliler nedenlerini şu şekilde ifade etmişlerdir: "Ben unutuyorum kullanmayı aslında basit de." (H.Ü). "Benim aklıma sizin anlattıklarını dışında hiç farklı örnek gelmiyor...." (F.A). 
Tablo IV

Velilerin Çocuklarının Öğrenmelerini Desteklemede Kullandıkları Örgütleme Stratejilerinin Haftalara Göre Dă̆glımı

\begin{tabular}{|c|c|c|c|c|c|c|c|c|}
\hline & \multicolumn{2}{|c|}{ 1.HAFTA } & \multicolumn{2}{|c|}{ 2.HAFTA } & \multicolumn{4}{|c|}{ 3.HAFTA } \\
\hline & Zihin haritaları & $\begin{array}{l}\text { Tablolaştırma / } \\
\text { Çizelgeleştirme }\end{array}$ & Zihin haritaları & $\begin{array}{l}\text { Tablolaştırma / } \\
\text { Çizelgeleştirme }\end{array}$ & Zihin haritaları & $\begin{array}{l}\text { Tablolaştırma / } \\
\text { Çizelgeleştirme }\end{array}$ & Anahatları çıkarma & Kümelendirme \\
\hline S.Ç (A) & - & - & $x$ & $x$ & $x$ & $x$ & - & - \\
\hline H.Ü (A) & - & - & $\mathrm{X}$ & $x$ & $x$ & $x$ & - & $\mathrm{x}$ \\
\hline R.Y (A) & - & - & $\mathrm{X}$ & - & $x$ & & - & - \\
\hline F.A (A) & - & $\mathrm{x}$ & $\mathrm{X}$ & $\mathrm{X}$ & $x$ & $\mathrm{x}$ & - & - \\
\hline G.Ç (Y) & - & - & $\mathrm{X}$ & $x$ & $x$ & $x$ & $x$ & - \\
\hline E.Y (D) & - & $x$ & $x$ & $x$ & $x$ & $x$ & $x$ & - \\
\hline C.T (A) & - & - & - & $x$ & $x$ & $x$ & $x$ & - \\
\hline \multirow[t]{3}{*}{ E.P (Ö) } & - & - & - & $x$ & $x$ & $x$ & $x$ & - \\
\hline & 4.HAFTA & & & 5.HAFTA & & 6.HAFTA & & \\
\hline & Zihin haritaları & $\begin{array}{l}\text { Tablolaştırma / } \\
\text { Çizelgeleştirme }\end{array}$ & $\begin{array}{l}\text { Anahatları } \\
\text { çıarma }\end{array}$ & Kümelendirme & $\begin{array}{l}\text { Anahatları } \\
\text { çıarma }\end{array}$ & Kümelendirme & Anahatları çıkarma & \\
\hline S.Ç (A) & $x$ & $X$ & $x$ & - & $\mathrm{X}$ & $x$ & $x$ & \\
\hline H.Ü (A) & $x$ & $x$ & - & $x$ & $x$ & $x$ & $x$ & \\
\hline R.Y (A) & $x$ & $x$ & - & $x$ & - & $x$ & - & \\
\hline F.A (A) & $x$ & $x$ & $x$ & $x$ & - & $x$ & - & \\
\hline G.Ç (Y) & $x$ & - & $x$ & $x$ & $x$ & $x$ & $x$ & \\
\hline E.Y (D) & $x$ & - & $x$ & - & $x$ & - & $x$ & \\
\hline С.T (A) & $x$ & $x$ & - & - & - & - & - & \\
\hline E.P (Ö) & $x$ & $x$ & $x$ & $x$ & $x$ & $x$ & $x$ & \\
\hline
\end{tabular}

Tablo V

Velilerin Çocuklarının Öğrenmelerini Desteklemede Kullandıkları Yineleme Stratejilerinin Haftalara Göre Dağılımı

\begin{tabular}{|c|c|c|c|c|c|c|c|c|c|c|}
\hline & \multicolumn{2}{|c|}{ 1.HAFTA } & \multicolumn{2}{|c|}{ 2.HAFTA } & \multicolumn{3}{|c|}{ 3.HAFYA } & \multicolumn{3}{|c|}{ 4.HAFTA } \\
\hline & $\begin{array}{c}\text { Değiştirmeden } \\
\text { yazma }\end{array}$ & $\begin{array}{l}\text { Aynen } \\
\text { okuma }\end{array}$ & $\begin{array}{c}\text { Değiştirmeden } \\
\text { yazma }\end{array}$ & $\begin{array}{l}\text { Aynen } \\
\text { okuma }\end{array}$ & $\begin{array}{c}\text { Değiştirmeden } \\
\text { yazma }\end{array}$ & $\begin{array}{l}\text { Aynen } \\
\text { okuma }\end{array}$ & Altını çizme & $\begin{array}{c}\text { Değiştirmeden } \\
\text { yazma }\end{array}$ & Aynen okuma & Altını çizme \\
\hline S.Ç (A) & - & - & - & - & - & - & $x$ & - & - & - \\
\hline H.Ü (A) & - & - & - & - & - & - & $x$ & - & - & - \\
\hline R.Y (A) & - & - & - & - & - & - & - & - & - & - \\
\hline F.A (A) & - & - & - & - & - & - & - & - & - & - \\
\hline G.Ç (Y) & - & - & - & - & - & - & - & - & - & $x$ \\
\hline E.Y (D) & $x$ & - & $x$ & $x$ & $x$ & $x$ & $x$ & $x$ & $x$ & $x$ \\
\hline С.T (A) & - & - & - & - & - & - & - & - & - & - \\
\hline
\end{tabular}


Velilerin dersten sonra hafta sonunda gerçekleştirdikleri destekleme çalışmaları incelendiğinde altı velinin kümelendirme stratejisini kullandığı görülmüştür. Veliler tarafından bu stratejinin kullanıldığı çalışma örneklerinden bazıları Şekil 4'te gösterilmiştir.
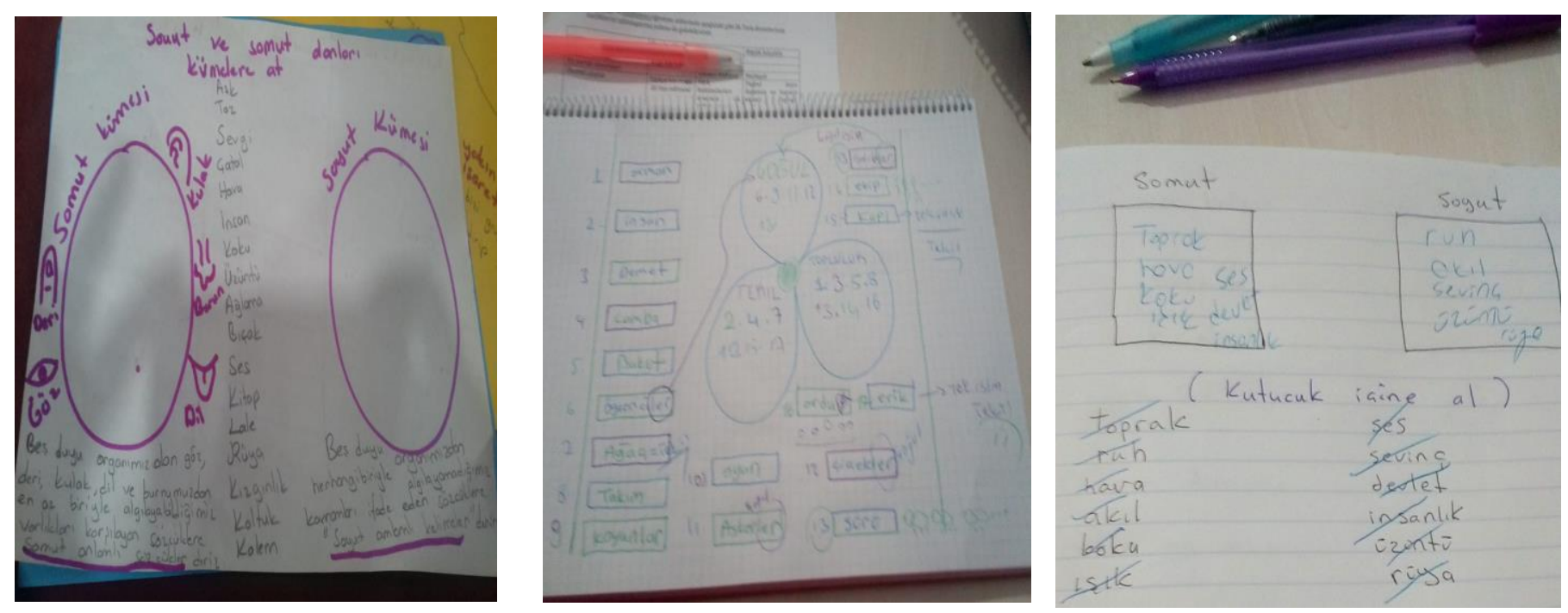

Şekil 4. Kümelendirme stratejisinin kullanıldığının gösteren çalışma kâğıtlarından örnekler

\section{Velilerin yineleme stratejilerini kullanma durumlarının geliştirilmesi}

Tablo V'te eylem araştırmasının uygulama sürecinde velilerin çocuklarının öğrenmelerini desteklemede kullandıkları yineleme stratejilerinin haftalara göre dağılımı verilmiştir. Değiştirmeden okuma/yazma stratejisinin kullanımının değiştiren öğrenme stiline sahip çocuklarda daha etkili sonuçlar verdiği söylenebilir. Araştırmada değiştiren öğrenme stiline sahip bir öğrenci bulunmaktadır. Bu nedenle çalışmada bu stratejiler genelde tek bir veli tarafından destekleme çalışmalarında kullanılmıştır. Değiştiren öğrenme stilinde etkili olan bir diğer yineleme stratejisinin de okuduklarının ya da daha önceden yazdıklarının altını çizme çalışmaları yapmak olduğu söylenebilir. Altını çizme çalışmalarının diğer öğrenme stillerine göre okuma çalışmalarından daha fazla hoşlanan özümleyici ve değiştiren öğrenme stillerine sahip çocukların Türkçe dersinde zamirler konusunda ders kitaplarındaki ya da hikâye kitaplarındaki bir okuma metnini açıp okuma metni içerisinde geçen zamirlerin altını çizmede de kullanıldığı görülmüştür. Araştırma süresince yineleme stratejileri farklı haftalarda farklı şekillerde velilerin yarısına yakını tarafından kullanılmıştır. Velilerin destekleme çalışmalarında çocukları ile yaptıkları uygulamalar ve öğrenme stillerinin özellikleri dikkate alındığında altını çizme çalışmalarının değiştiren öğrenme stilinde yineleme stratejileri içerisinde birebir tekrarlarda; değiştiren ve özümleyici öğrenme stillerinde ise öğrenme konusunun ana hatlarını çıkarma çalışmasını daha kolay yapabilmek için bu teknik ile birlikte kullanımında etkili olduğu söylenebilir.

\section{Velilerin anlamayı izleme stratejilerini kullanma durumlarının geliştirilmesi}

Tablo VI'da eylem araştırmasının uygulama sürecinde velilerin çocuklarının öğrenmelerini desteklemede kullandıkları anlamayı izleme stratejilerinin haftalara göre dağılımı verilmiştir. Anlamayı izleme stratejileri farklı öğrenme stillerine sahip tüm öğrencilerin öğrenmelerini gerçekleştirirken kullanmaları gereken stratejilerdir. Bu çalışmada anlamayı izleme stratejileri planlama, uygulama ve değerlendirme olmak üzere üç aşamada ele alınmıştır. Araştırmacı velilere anlamayı izleme stratejilerinin her bir aşamasında neler yapılması gerektiğini örneklendirerek açıklamıştır. Veliler ilk haftalarda anlamayı izleme stratejilerini tam anlamıla gerçekleştirememiş olsalar da velilerin bazılarının çocuklarının öğrenme ihtiyaçlarını ve buna uygun basit öğrenme amaçları oluşturmalarını sağladığı söylenebilir.

Velilerden bazıları gerçekleştirdikleri destekleme çalışmalarında anlamayı izleme stratejilerini nasıl kullandıklarına ilişkin görüşlerini ders esnasında ifade etmişlerdir. Bir velinin görüşü şu şekildedir: "Evet ben Poyraza sordum ona göre odaklanalım diye. Bileşik kesirleri zor anladım biraz anne dedi biz de ona daha çok odaklandık." (E.Y). 
Tablo VI'dan anlaşılabileceği gibi değerlendirme aşamasının planlama ve uygulama basamağına göre velilere daha zor geldiği söylenebilir. Bu stratejilerin ilk haftalarda beklenilen sayıda ve düzeyde veli tarafından kullanılamamış olmasına ilişkin 4. haftanın sonunda bir komite uzmanının görüşü şu şekilde olmuştur: "Belki araştırmacı anlamayı izleme stratejileri için hazır bir şablon üretebilir. Planlama, uygulama ve değerlendirme sütunları olan bir çizelge mesela." (Uzman-1).

Komite üyesinin görüş ve önerileri doğrultusunda 4. hafta velilere bu stratejileri nasıl kullanabileceklerine ilişkin hazır bir form kullanılmasına karar verilmiştir. Tablo VI'da görüldüğü gibi 4. hafta yapılan destekleme çalışması sonucunda velilerin büyük bir çoğunluğunun anlamayı izleme stratejilerini kullandıkları görülmüştür. Velilerin çocukları ile birlikte anlamayı izleme stratejilerini kullanarak hazırladıkları çalışma kâğıtlarından bazıları Şekil 5'te sunulmuştur:
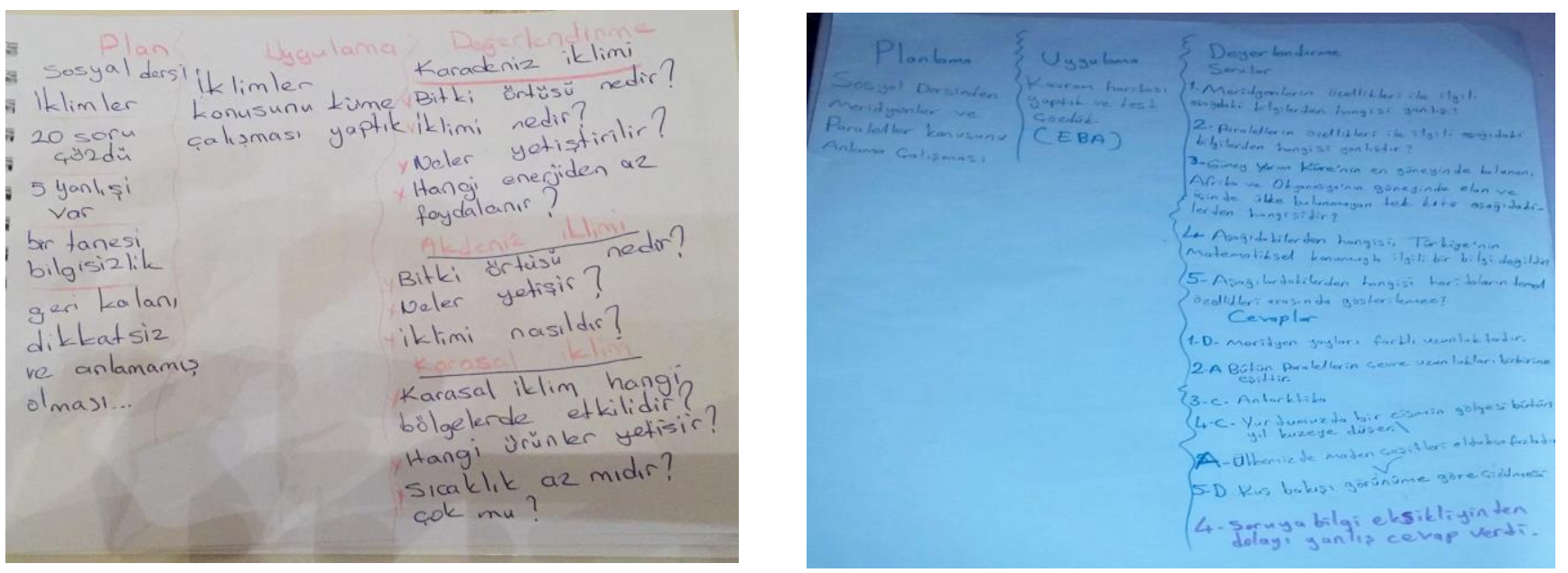

Şekil 5. Anlamayı izleme stratejilerinin kullanıldığını gösteren çalışma kâğıtlarından örnekler

Veliler 4. haftadan son haftaya kadar gerçekleştirdikleri anlamayı izleme stratejilerine ilişkin derste ve/veya whatsapp grubu üzerinden de görüşlerini belirtmişlerdir. Bir velinin ifadesi şu şekildedir:

E.Y: Planlama başta olduğu için unutmuyoruz da değerlendirmeyi uygulamadan sonra unuttuk önce biz. Ama sonra sorduk tabi sorular kesirlere yönelik. Ama işte Poyraz kendi kendine sormuyor da ben öğrendin mi anladın mı diye sorunca cevaplıyor. Daha çok ben yaptım. Zamanla kendi de yapar inşallah. 
Tablo VI

Gülten Feryal GÜNDÜZ

Eylem Araştırmasının Uygulama Sürecinde Velilerin Çocuklarının Öğrenmelerini Desteklemede Kullandıkları Anlamayı İzleme Stratejilerinin Haftalara Göre Dă̆ılımı

\begin{tabular}{|c|c|c|c|c|c|c|c|c|c|c|c|c|}
\hline & \multicolumn{3}{|c|}{ 3.HAFTA } & \multicolumn{3}{|c|}{ 4.HAFTA } & \multicolumn{3}{|c|}{ 5.HAFTA } & \multicolumn{3}{|c|}{ 6.HAFTA } \\
\hline & Planlama & Uygulama & Değerlendirme & Planlama & Uygulama & Değerlendirme & Planlama & Uygulama & Değerlendirme & Planlama & Uygulama & Değerlendirme \\
\hline S.Ç (A) & $x$ & $x$ & $X$ & $x$ & $x$ & $x$ & $x$ & $X$ & $\mathrm{X}$ & $X$ & $X$ & $X$ \\
\hline H.Ü (A) & $x$ & $x$ & $x$ & $x$ & $x$ & $x$ & $x$ & $x$ & $x$ & $x$ & $x$ & $x$ \\
\hline R.Y (A) & $x$ & & $x$ & $x$ & $x$ & $x$ & $x$ & $x$ & $x$ & $x$ & $x$ & $x$ \\
\hline F.A (A) & $x$ & $x$ & - & $x$ & $x$ & $x$ & $x$ & $x$ & - & $x$ & $x$ & $x$ \\
\hline G.Ç $(Y)$ & $x$ & $x$ & - & $x$ & $x$ & - & $x$ & $x$ & - & $x$ & $x$ & $x$ \\
\hline E.Y (D) & - & - & - & $x$ & - & - & - & - & - & $x$ & $x$ & $x$ \\
\hline C.T (A) & - & - & - & - & - & - & - & - & - & - & - & - \\
\hline E.P $(\ddot{)})$ & - & - & - & - & - & - & - & - & - & $x$ & $x$ & - \\
\hline
\end{tabular}

Tablo VII

Eylem Araştırmasının Uygulama Sürecinde Velilerin Çocuklarının Öğrenmelerini Desteklemede Kullandıkları Duyuşsal Stratejilerin Haftalara Göre Dağıllmı

\begin{tabular}{|c|c|c|c|c|c|c|c|c|c|}
\hline & \multicolumn{3}{|c|}{ 3. HAFTA } & \multicolumn{3}{|c|}{ 4. HAFTA } & \multicolumn{3}{|c|}{ 5. HAFTA } \\
\hline & Motive etme & Özgüvenini artırma & Dikkat odaklama & Motive etme & Özgüvenini artırma & Dikkat odaklama & Motive etme & Özgüvenini artırma & Dikkat odaklama \\
\hline S.Ç (A) & $x$ & $x$ & - & $x$ & $x$ & - & $x$ & & \\
\hline H.Ü (A) & $x$ & $x$ & $x$ & $x$ & $x$ & - & $x$ & $x$ & $x$ \\
\hline R.Y (A) & $x$ & $x$ & - & $x$ & - & $x$ & $x$ & - & - \\
\hline F.A (A) & $x$ & $x$ & - & $x$ & $x$ & - & $x$ & $x$ & - \\
\hline G.Ç (Y) & - & - & $x$ & $x$ & - & $x$ & $x$ & - & $x$ \\
\hline E.Y (D) & - & - & $x$ & $x$ & $x$ & $x$ & $x$ & $x$ & - \\
\hline C.T (A) & $x$ & - & $x$ & $x$ & $x$ & $x$ & $x$ & - & $x$ \\
\hline \multirow[t]{3}{*}{ E.P (Ö) } & $x$ & - & - & $x$ & - & - & $x$ & $x$ & - \\
\hline & 6. HAFTA & & & & & & & & \\
\hline & Motive etme & Özgüvenini artırma & Dikkat odaklama & & & & & & \\
\hline S.Ç (A) & $x$ & $x$ & - & & & & & & \\
\hline H.Ü (A) & $x$ & $x$ & - & & & & & & \\
\hline R.Y (A) & $x$ & - & $x$ & & & & & & \\
\hline F.A (A) & $x$ & $x$ & - & & & & & & \\
\hline G.Ç (Y) & $X$ & - & $X$ & & & & & & \\
\hline E.Y (D) & $x$ & $x$ & $x$ & & & & & & \\
\hline C.T (A) & $x$ & $x$ & $X$ & & & & & & \\
\hline E.P (Ö) & $X$ & - & - & & & & & & \\
\hline
\end{tabular}




\section{Velilerin duyuşsal stratejileri kullanma durumunun geliştirilmesi}

Tablo VII' de eylem araştırmasının uygulama sürecinde velilerin çocuklarının öğrenmelerini desteklemede kullandıkları duyuşsal stratejilerinin haftalara göre dağılımı verilmiştir. Araştırmacı çocuklarını çalışmaya motive etme, özgüvenlerini artırma ve dikkat dağınıklığı konusunda velileri bilgilendirmiştir. Duyuşsal stratejilerin kullanımına ilişkin veli görüşleri şu şekildedir:

H.Ü: Mert çok duygusal bir çocuk. Bir şeyi doğru yaptığında ya da başardığında pohpohlanmayı çok sever. Aferin benim oğluma diyeceğim illaki. Ben de öyle yapıyorum.

E.Y: Poyraz çok sessiz sakin bir çocuk. Çalışıyor da aslında ama işte dikkat etmiyor çalışırken. Önemli noktaları kaçırıyor. Ben de o nedenle bir konuyu okuduğunda ya da çalıştığında acele etmemesini, bazen okuduğunu bir daha okumasını istiyorum.

Velilere kullanabilecekleri temel duyuşsal stratejiler verilirken uzmanların ilk hafta önemle dikkat edilmesi gerektiğini belirttikleri noktalar şunlar olmuştur:

Uzman-1: Genelde veliler benim oğlum sözelci sayısalcı gibi ayrımlara gitmiş ve çocukların sevmedikleri stratejileri buna bağlamışlar. Buna dikkat edilmesi gerektiğini düşünüyorum

Uzman-2: Hani bu öğrenciler ben sosyal sevmiyorum, ben matematikçiyim gibi davranıyorlar başka bir deyişle kendilerini bazı derslere kapatabiliyorlar kendilerini ya da ben matematik sevmiyorum deyip. .... Bu durum aşılmadan diğer yapılan uygulamalar bir işe yaramayabilir. Bu noktada velilerin olası böyle bir durumda ne yapmaları gerektiğini bilmeleri gerektiğini düşünüyorum.

Araştırmacı uzmanların bu görüş ve önerileri doğrultusunda velilerin hangi duyuşsal stratejileri nasıl kullanabileceklerine ilişkin açıklama yapmıştır.

A: .......unutulmaması gereken önemli bir nokta çocuklarımızın eğitimi sistemimizdeki sınavlarda, öğrenmelerinde ve hayatları boyunca kullanacakları temel yeterliklere sahip olabilmeleri ve kullanabilmeleri için özellikle temel derslere ilişkin genel bilgi ve becerilere sahip olmaları gerekmektedir. Bunu çocuğunuza açıklamalı, tüm derslere ilişkin öğrenmelerinin gerçekleştirilmesinin ve çalışılmasının neden önemli olduğunu açıklamalı, günlük hayattan örnekler vererek önemini vurgulamalısınız.

Araştırmacı çocuklarını nasıl çalışmaya motive edecekleri, özgüvenlerini artırmanın önemi ve ders çalışırken dikkat dağınıklığı söz konusu ise neler yapabilecekleri konularında velilere bilgi vermiştir. Araştırmacı velilere duyuşsal stratejileri nasıl uyguladıklarını sormuştur. Velilerden beşi motivasyonunu artırma, dördü özgüvenini artırma ve dördü de dikkat odaklama stratejilerini kullandıklarını belirtmişlerdir. Bir velinin görüşü şu şekildedir: "Ben de Poyrazın bazı şeyleri yapmasına çok şaşırdı̆̆̆mda ona böyle zor bir çalışmayı nasıl da çabuk yaptın anlamında şaşırdı̆̆ımı ve beğendiğimi gösteriyorum davranışlarımla. O da onu çok mutlu ediyor ve özgüvenini artırıyor." (E.Y).

Velilere duyuşsal stratejileri kullanırken çocuklarının öğrenme stilleri özelliklerini de dikkate almayı unutmamaları söylenmiştir.
A: .....Mesela değiştiren öğrenme stilinde öğrenme durumunda sabırlı olma ancak bir eylemde bulunmaktan kaçınma özelliği var. Seçenekler arasında seçim yapma, karar vermede güçlük çekme de özellikleri arasında. Ne yapabiliriz o zaman?
H.Ü: Dersleri ile ilgili bir işi yapması, uygulaması için motive edebilir annesi.
E.Y: Kendine güvenmesini de sağlayabilirim hani aldığın kararlara güven, yanlış olsa da sorun değil gibi.
A: Evet aynen değiştiren öğrenme stilinde kendisine güvenmesini, kararlı olmaya ve eylemde bulunmasına yönelik güdülenmesini sağlayabiliriz.

Bununla birlikte velilerin bu en fazla şikâyet ettikleri konulardan biri çocuklarının bazen isteksiz olması olmuştur. Bu nedenle duyuşsal stratejilerde çocuklarını öğrenmeye karşı nasıl motive edebileceklerine ilişkin farklı stratejiler-yöntemler açılanmıştır: "Çocuğunuzu motive etmenin bir sürü yolu var. Öğrenmenin önemini anlatma, öğrenmesine bağhl olarak ileride gerçekleşmesini istediği bir hayali üzerine konuşma, istediği bir etkinliği birlikte yapma, takdir etme, başarı duygusunu tatmasına yardımoı olma gibi pek çok yöntem kullanılabilir...." (Araştırmacı).

Tablo VII'de görüldüğü gibi velilerin üçüncü haftadan itibaren anlatılmaya başlanan duyuşsal stratejileri ilk zamanlar olmasa da ilerleyen haftalarda özellikle çocuklarının çalışmaya karşı isteklerini ve gayretlerini artırdığını görmeleri ile birlikte bu stratejileri düzenli olarak uyguladıkları görülmüştür. 


\section{Velilerin öğrenme stillerine dayalı destekleme çalışmalarına yönelik görüssleri}

Velilere gerçekleştirilen veli eğitimi çalışmasının kendileri ve çocukları üzerindeki etkileri sorulmuştur. Yapılan görüşmelerden elde edilen görüşler ve bu görüşlere ait frekans dağılımları Tablo VIII'de sunulmuştur.

Tablo VIII

Velilerin Gerçekleştirilen Veli Ĕ̆itimi Çalışmasına İlişkin Görüşleri

\begin{tabular}{ll}
\hline Kodlar & F \\
\hline Çocuğu ile daha düzenli çalışma & 8 \\
\hline Çocuğunun derslerini nasıl destekleyeceğini öğrenme & 8 \\
\hline Çocuğunun ders çalışmayı daha fazla sevmesi & 8 \\
\hline Çocuğunun başarısının artması & 6 \\
\hline Çocuğunun eğitimine daha fazla zaman ayırma & 5 \\
\hline Özgüveninin artması & 5 \\
\hline Öğrenmeye daha fazla önem verme & 5 \\
\hline
\end{tabular}

Tablo VIII'de görüldüğü gibi velilerin tamamı çocuğu ile daha düzenli çalışmaya başladığını, onun derslerini nasıl destekleyeceğini öğrendiğini ve çocuğunun ders çalışmayı daha fazla sevdiğini ifade etmiştir. Bazı veliler bu konudaki görüşlerini şu şekilde ifade etmişlerdir:

H.Ü: ... Daha düzenli ve verimli ders çalışmaya başladık.

R.Y: Biz bu destekleme çalışmaları ile daha çok çalışmaya başladık. Yani ders çalışma süremiz değişti.

F.A: ... Efe şu an kendisi okuldan gelir gelmez çalışmaya başlıyor artık daha istekli ve derslerini daha çok seviyor. ...

Velilerin yarısından fazlası gerçekleştirdikleri destekleme çalışmaları ile kendisine olan güveninin artığını, öğrenmeye daha fazla önem verdiğini, çocuğunun başarısının artığını ve onun eğitimine daha fazla zaman ayırdığını belirtmişlerdir. Bu konudaki veli görüşlerinden bazıları şunlardır:

E.Y: Kendime olan güvenim arttı. Ben artık oğlumun çalışmalarını nasıl destekleyeceğimi öğrendim ve sonrasında da devam edeceğim....

C.T: Ben de çok büyük değişiklikler oldu artık kendim de öğrenmeye daha çok önem veriyorum. Önceden ben öğretemem, ben anlatamam, ben yapamam diyordum ama şimdi artık yapabileceğimi gördüm....

G.Ç: Yunus Emre'nin notlarında çok ciddi bir artış oldu. Destekleme çalışmalarını yaptığımız Türkçe, Matematik ve Sosyal Bilgiler derslerinde sınav notları yükseldi..

\section{Öğrencilerin öğrenme stillerine dayalı destekleme çalışmalarına yönelik görüşleri}

Velilerin çocuklarına gerçekleştirilen veli eğitimi çalışmasının kendileri ve velileri üzerindeki etkileri sorulmuştur. Yapılan görüşmelerden elde edilen görüşler ve bu görüşlere ait frekans dağılımları Tablo IX'da sunulmuştur.

Tablo IX

Öğrencilerin Gerçekleştirilen Veli Ĕ̆itimi Çalışmasına İlişkin Görüşleri

\begin{tabular}{lc}
\hline Kodlar & F \\
\hline Nasıl ders çalışacaklarını bilme & 8 \\
\hline Velilerinin derste kendilerine daha fazla yardımcı olabilmeleri & 8 \\
\hline Velileriyle birlikte daha fazla ders çalışma & 6 \\
\hline Derslere katılımının artması & 6 \\
\hline Akademik başarılarının artması & 6 \\
\hline Özgüveninin artması & 5 \\
\hline
\end{tabular}

Tablo IX'da görüldüğü gibi öğrencilerin tamamı gerçekleştirilen destekleme çalışmaları ile artık nasıl ders çalışacaklarını bildiklerini ve velilerinin kendilerine daha fazla yardımcı olabildiklerini ifade etmişlerdir. Bu konulara ilişkin öğrencilerin görüşlerinden bazıları şunlardır: "... derslere nasıl çalışacağımı biliyorum artık." (M.Ü). "Annem önceden Sosyal Bilgiler ve Matematiğin bazı konuların bilmiyordu ama şimdi sizin sayenizde bunları öğrendiği için şimdi bana daha çok yardımcı oluyor, ona derslerle ilgili sorduğum soruları daha fazla cevaplayabiliyor..." (E.A).

Öğrencilerin yarısında fazlası destekleme çalışmaları sonucu velileriyle birlikte daha fazla ders çalıştıklarını, okulda derse daha katıldığını, başarısının ve özgüveninin artı̆̆ını belirmiştir. Bu konularda 
Öğrenmeyi Öğrenme Üzerine Veli Eğitimi ....

görüşlerini ifade eden öğrencilerden bazılarının ifadeleri şu şekildedir:

G.Ç: Annemle önceden daha az birlikte çalışıyorduk annem genelde ev işleri yapıyordu ama şimdi çok güzel oldu birlikte çalışıyoruz. .... Bir de derslerime artık daha fazla yardımcı olabiliyor....

M.Ü: .... Annemle yaptı̆̆ımız etkinlikler sonucu sosyal bilgileri daha çok sevmeye başladım. Öğrenmelerim daha çok aklımda kalmaya başladı....

P.Y: .... Kendime olan güvenim arttı. Matematik öğretmeni mesela kim bu soruyu çözmek ister dediğinde ben hemen parmak kaldırıyorum tahtaya kalkmak için.

E.A: Destekleme çalışmalarını yaptı̆̆ımız üç dersten de notlarım arttı hatta sosyal bilgiler dersinde sınıfta en yüksek notu ben aldım....

Hem veli hem de velilerin çocuklarının veli eğitimi çalışmasına ilişkin görüşleri genel olarak değerlendirildiğinde uygulamanın akademik başarıyı artırdığı, birlikte daha fazla zaman geçirmelerine olanak sağladığı, ders çalışmanın ya da desteklemenin nasıl olacağı konusunda bilgi sahibi olmalarına katkı sağladığı, öğrenmeye karşı olumlu tutumlar oluşturduğu ve kendilerine olan güvenlerini artırdığı görülmüştür.

\section{Sonuç ve Tartıșma}

Ev temelli aile katılımını artırmaya yönelik tasarlanan veli eğitimi çalışmasının hazırlanmasında öncelikle alanyazın ve veli görüşleri dikkate alınmış ve öğrenme ihtiyaçları, bu ihtiyaçlara uygun öğrenme amaçları ile öğrenme konuları belirlenmiştir. Araştırmadan elde edilen bu bulgu, ev temelli aile katılımı çalışmalarında velilerin eğitimsel ihtiyaçlarının belirlenmesinin önemli olduğunu belirten çalışmalarla tutarlılık göstermektedir (DeSpain ve diğerleri, 2018; Garst ve McCawley, 2015; Hornby ve Blackwell, 2018; Stanley ve diğerleri, 2017). Derslerin süresinin ne kadar olacağının velilerle belirlenmesinin ve velilerle hem yüz yüze hem de whatsapp grubu üzerinden iletişim kurulmasının, onların araştırmaya katılımda devamlılıklarında ve destekleme çalışmalarını etkili gerçekleştirmelerinde önemli olduğu söylenebilir. Sosyal ağ kullanımının etkili olmasının en önemli nedenlerinden birisi ise velilerin bu tür destekleme çalışmalarına zaman ve mekan sınırlaması olmadan katılabilmeleri olabilir. Alanyazındaki araştırmalar da aile katılımında Facebook, wikiler, Twitter, Whatsapp gibi sosyal ağ kullanılmasının onların bu sürece daha fazla katılmalarını, daha fazla iletişim kurmalarını ve okul - veli arasında bilgi paylaşımında bulunmasını sağladığını göstermektedir (Chairatchatakul, Jantaburom ve Kanarkard, 2012; Curtiss ve diğerleri, 2015; Olmstead, 2013).

Veli eğitimi çalışması tasarlanırken uygulama süresinde velilerin nasıl güdülenebileceği de dikkate alınmıştır. Araştırmacı bunun için velilerle sıcak bir iletişim kurmaya, etkin katılımlarını sağlamaya, zaman zaman onlara övgü dolu sözler söylemeye ve uygulama süresince ilgi ve ihtiyaçlarının neler olduğuna dikkat etmeye çalışmıştır. Bu güdüleme etkinliklerinin velilerin özgüvenlerinin artmasını, sahip oldukları bilgi yönünden kendilerini yeterli hissetmelerini, derse aktif katılımlarını ve devam etmelerini sağladığı söylenebilir. Alanyazındaki aile katılımı çalışmalarında da velilerin ev temelli aile katılımı çalışmalarına yönelik güdülenmelerinde özyeterliliklerinin, çocuklarının ve öğretmenlerinin kendilerinden yardım istemelerinin, yardım edebilecekleri konusunda cesaretlendirilmelerinin, yardımlarının takdir edilmesinin, katılım sağlayabilecek zamanlarının olmasının ve çocuklarının gelecek öğrenme başarılarına ilişkin beklentilerinin olmasının önemli olduğu ifade edilmiştir (Kigobe, Ghesquiere, Ng'Umbi ve Leeuwen, 2018; Walker, Ice, Hoover-Dempsey ve Sandler, 2011; Zimmerman, Bonner ve Kovach, 1996).

Veli eğitimi çalışmasının uygulanması sürecinde genellikle velilerin ve çocuklarının öğrenme stillerine uygun öğrenme stratejilerini kullanmayı tercih ettikleri görülmüştür. Bu bağlamda çocukların kullandıkları öğrenme stratejilerinin onların öğrenme stillerine göre farklılaşttı̆̆ söylenebilir. Araştırmadan elde edilen bu bulgu öğrencilerin öğrenme stilleri ile kullandıkları öğrenme stratejileri arasında ilişki olduğu sonucuna ulaşan araştırmaların bulguları ile örtüşmektedir (Becta, 2005; Durukan, 2013; Evin Gencel ve Köse, 2011; Güven, 2004; Yılmaz, 2011). Bununla birlikte araştırmada dikkat çeken bir diğer önemli bulgu, çocukların bazı zamanlarda ve derslerde öğrenme stillerine uygun önerilen öğrenme stratejilerini kullanmamaları; zaman zaman farklı öğrenme stilinin özelliklerine daha çok uygun olan farklı öğrenme stratejilerini de çalışmalarında kullanmak istemeleri ve kullanmaları olmuştur. Bu durum bazı öğrenenlerin birden fazla öğrenme stiline sahip olmaları ve derslere göre öğrenme stillerinin değişebilmeleri durumu ile açılanabilir. Alan yazındaki 
araştırmalar da bazı öğrencilerin birden fazla öğrenme stiline sahip olabileceklerini ya da öğrencilerin sahip oldukları öğrenme stillerinin çeşitli derslere göre farklılaşabileceğini göstermektedir (Biçer, 2010; Claxton, 2009; Li ve He, 2016).

Uygulama süreci boyunca ve bu sürecin sonunda hem velilerle hem de bu velilerin çocukları ile gerçekleştirilen görüşmelerden elde edilen veriler öğrenme stillerine uygun öğrenme stratejilerini temele alan bu çalışmanın çocukların akademik başarısını artırdığını göstermektedir. Uygulama sonucunda öğrencilerin akademik başarılarının artmasında çocukların zamanla kendi öğrenme yollarının farkında olarak neyi ne zaman ve nasıl öğrenmeleri gerektiklerine kararlar verebilmeleri ve öğrenmelerini yönetebilmeleri etkili olmuş olabilir. Alan yazında da öğretimin öğrenme stillerine dayalı tasarımlanmasının akademik başarı üzerinde etkili olduğunu gösteren pek çok çalışma bulunmaktadır (Dunn ve Honigsfeld, 2013; Jahanbakhsh, 2012; Kanadlı, 2016; Lauria, 2010; Li ve He, 2016; Rao, 2002). Öğrenciler, en iyi nasıl öğreneceklerini bildiklerinde ve öğrenme stilleri ile öğrenme stratejilerinin farkında olduklarında öğrenmelerini kolaylaştırıcı stratejileri kullanmakta, daha etkili çalışmakta ve ne çalıştıklarının değil, nasıl çalıştıklarının önemli olduğunun farkına varmaktadırlar (Dunn ve diğerleri, 2009).

Uygulanan veli eğitimi çalışması çocukların sadece akademik başarılarını değil; öğrenmeye karşı tutumlarını, derse katılımlarını ve öz yeterlilik algılarını da olumlu yönde etkilemiştir. Uygulamaya ilişkin öğrenci görüşlerinden elde edilen bulgulara dayalı olarak böyle bir sonucun elde edilmesinde çocuğun istediğinde ve kendi öğrenme yollarını bilerek çalışmalarını gerçekleştirdiğinde akademik başarısının artmasını görmesinin etkili olduğu söylenebilir. Bozkurt ve Aydoğdu (2009) gerçekleştirdikleri araştırmalarında Dunn ve Dunn öğrenme stili modeline dayalı uygulanan fen eğitiminin, öğrencilerin bu derse karşı tutumlarını geliştirdiği sonucuna ulaşmışlardır. Alan yazına göre de çocuklarının öğrenme stillerinin farkında olmaları ve uygun öğrenme stratejilerini kullanmaları hem öğrenmeye karşı olumlu tutumlar geliştirilmesini hem de onların özyeterlikleri, motivasyonları, derse katılımları gibi duyuşsal özeliklerini olumlu yönde etkilemektedir (Bonney, Cortina, Smith-Darden ve Fiori, 2008; Dunn ve Honigsfeld, 2013; Dunn ve diğerleri, 2009; Gettinger ve Walter, 2012; Horino ve Ichikawa, 1997; Murayama, 2003; Sadi ve Uyar, 2013; Sato, 1998; Schunk ve Zimerman, 2008; Williams, Swift, Williams ve Van Daal, 2017). Araştırmadan elde edilen bulgular doğrultusunda öğrenme stillerine dayalı bir destekleme çalışmasının çocukların akademik başarısında ve sözü edilen duyuşsal özelliklerinin gerçekleştirilmesinde, öğrenme stillerine dayalı bir destekleme çalışması gerçekleştirilmesinin ve aileleri tarafından daha fazla desteklenmelerinin birlikte etkili olduğu söylenebilir. Yapılan araştırmalar da ailelerin çocuklarının öğrenmelerini desteklemesinin öğrenci başarısını ve motivasyonunu artırdığını; öğrencilerin özdüzenleyici ve çalışma becerilerini geliştirdiğini ve velilerin özerklik desteği ile öğrencilerin özdüzenleyici öğrenme stratejileri arasında pozitif bir ilişki olduğunu göstermektedir (Baker ve Iruka, 2013; Catalano ve Catalano, 2014; Cheung ve Pomerantz, 2011 Patall ve diğerleri, 2008; Pino-Pasternak ve Whitebread, 2010; Robledo ve Garcia, 2006; Sha, Looi, Chen, Sewo ve Wong, 2012).

Gerçekleştirilen veli eğitimi çalışması ile velilerin de kendilerine olan güvenleri artmış ve benzer destekleme çalışmalarına araştırma sonrasında da devam edeceklerini belirtmişlerdir. Bunun önemli sebeplerinden birinin velilerin artık çocuklarının dersleri ve öğrenmelerini nasıl destekleyecekleri konusunda bilgi sahibi olmaları olduğu söylenebilir. Veliler eğitim düzeyleri düşük olduğunda ve/veya çocuklarının öğrenmelerini nasıl destekleyeceklerini bilemediklerinde aile katılımı çalışmalarına katılmakta isteksiz davranmaktadırlar (Bæck, 2010; Goodall ve Montgomery, 2014; Hornby ve Blackwell, 2018; Moroni ve diğerleri, 2015; Öz, 1983, akt. Porsuk ve Kunt, 2012). Aile katılımı konusunda önemli çalışmaları olan HooverDempsey ve diğerleri (2005) katılımın artmasını, ailelerin özyeterliklerinin artması ile ilişkilendirmekte ve bu özyeterliği velilerin sahip oldukları bilgi ve becerilerle çocuklarının eğitimine nasıl bir katkı sağlayabileceklerine yönelik inançları olarak tanımlamaktadırlar. Gubbins ve Otero (2018) da kişilerin daha etkili ve daha fazla faydalı olabileceğini düşündüğü etkinliklere katılmada daha istekli olduğunu gösteren pek çok araştırma bulunduğunu ifade etmektedirler. Aile eğitimi programları sayesinde veliler, aile katılımındaki görev ve sorumluluklarını gerçekleştirirken kendilerini daha yeterli ve rahat görmekte; bu eğitimler ile özgüvenleri ve motivasyonları artmaktadır (Wilder Research, 2016). 
Araştırmada dikkat çeken bir diğer önemli nokta katılımcıların, biri hariç diğerlerinin annelerden oluşmasıdır. Araştırmadan elde edilen bu bulgu doğrultusunda, aile içinde annelerin çocuklarının eğitimlerinden birinci derece sorumlu tutuldukları söylenebilir. Alanyazındaki aile katılımı çalışmaları incelendiğinde de bu araştırmalarda çocuklarının eğitimlerinin desteklenmesinde annelerin, babalara göre daha ön planda olduğu görülmektedir (Bräu, Harring ve Weyl, 2017; Edwards ve Gillies, 2011; Jezierski ve Wall, 2017; Lareau, 2003; Wall, 2012).

\section{Sınırlılıklar / İleriye Dönük Araştırmalar}

Eylem araştırması deseninde az sayıda katılımcı ile gerçekleştirilmiş olan bu veli eğitimi çalışmasının deneysel çalışmalar yoluyla daha geniş kitlelerle gerçekleştirilmesinin elde edilen bulguların genellenebilmesi açısından önemli olacağı düşünülmektedir. Öğrenmeyi öğrenme, daha geniş bir perspektifle ele alındığında bu becerilerin geliştirilmesi öğrenme stilleri ve öğrenme stratejilerinden daha fazlasını gerektirmektedir. Bu araştırmada eylem araştırması süreci, eğitim-öğretim yılının birinci döneminin süresi ve katılımcıların öğrenmeyi öğrenmeye ilişkin hiçbir önbilgilerinin olmaması dikkate alınarak öğrenmeyi öğrenmenin sadece ilk aşamalarına yönelik gerçekleştirilmiştir. Öğrenmeyi öğrenme konusunda daha ileri düzeyde olan veliler ve çocuklar için, öğrenmeyi öğrenmenin daha ileriki aşamaları dikkate alınarak aile eğitimleri düzenlenebilir. Araştırmacının ortaokul 6. sınıf Türkçe, Matematik ve Sosyal Bilgiler dersi konularıyla sınırlı olması, araştırmanın yürütülmesinde önemli bir kolaylık sağlamıştır. Benzer bir aile eğitiminin uygulanmasında, uygulayıcıların derslere ilişkin bilgi yetersizliği olması durumunda ders öğretmenleri ile işbirliği yapılması sağlanmalıdır. Ev temelli aile katılımının ve çocukların öğrenmeyi öğrenme becerilerinin erken okul yaşlarında geliştirilmiş olması önemli olmaktadır. Bu nedenle benzer bir çalışmanın okul öncesi öğretmenleri, velileri ve çocukları ile gerçekleştirilmesinin alana katkı sağlayacağı düşünülmektedir.

\section{Kaynaklar}

Ashby, N. (2006). Activity-filled family meeting leads to increases in parent involvement, student performance at Maryland school (Viers Mill Elementary School). The Achiever, 5(4), 1-6.

Bæck, U.K. (2010) Parental involvement practices in formalized home-school cooperation. Scandinavian Journal of Educational Research, 54(6), 549-563. doi: 10.1080/00313831.2010.522845

Baker, C. E. ve Iruka, I. U. (2013). Maternal psychological functioning and children's school readiness: The mediating role of home environments for African American children. Early Childhood Research Quarterly, 28(3), 509-519. doi:10.1016/j.ecresq.2013.02.004 adresinden erişildi.

Becta. (2005). Learning styles: An introduction to the research literature. 10.06 .2019 tarihinde http://dera.ioe. ac.uk/14118/1/learning_styles.pdf adresinden erişildi.

Bhargava, S. ve Witherspoon, D. P. (2015). Parental involvement across middle and high school: Exploring contributions of individual and neighborhood characteristics. Journal of Youth Adolescence, 44(9), 1702-1719.

Biçer, M. (2010). Illköğretim 6, 7 ve 8. sını öğrencilerinin sını düzeyleri, cinsiyetleri, akademik başarıları ve ders grupları ile öğrenme stilleri arasındaki ilişki (Yayımlanmamış yüksek lisans tezi). Yıldız Teknik Üniversitesi, İstanbul.

Bonney, C. R., Cortina, K. S., Smith-Darden, J. P. ve Fiori, K. L. (2008). Understanding strategies in foreign language learning: Are integrative and intrinsic motives distinct predictors? Learning and Individual Differences, 18(1), 1-10.

Bozkurt, O. ve Aydoğuu, M. (2009). İlköğretim 6. sinıf fen bilgisi dersinde Dunn ve Dunn ögrenme stili modeline dayalı ögretim ile geleneksel ögretim yöntemlerinin ögrencilerin akademik bașarı düzeyleri ve tutumlarına etkisinin karșılaș,ırılması . Ilköğretim Online, 8(3), 741-754.

Bräu, K., Harring, M. ve Weyl, C. (2017). Homework practices: Role conflicts concerning parental involvement. Ethnography and Education, 12(1), 64-77. 
Bridgeland, J. M., DiIulio, J. J., Streeter, R. T., Mason, J. R. ve Civic, E. (2008). One dream, two realities: Perspectives of parents on America's high schools. Washington, DC: Civic Enterprises.

Catalano, H. ve Catalano. C. (2014). The importance of the school-family relationship in the child's intellectual and social development. Procedia-Social and Behavioral Sciences, 128, 406-414. doi:10.1016/j.sbspro.2014.03.179.

Chairatchatakul, A., Jantaburom, P. ve Kanarkard, W. (2012). Using social media to improve a parent-school relationship. International Journal of Information and Education Technology, 2(4), 378-381.

Chen, W. ve Gregory, A. (2009). Parental involvement as a protective factor during the transition to high school. The Journal of Educational Research. 103(1), 53-62.

Cheung, C. S. ve Pomerantz, E. M. (2011). Parents' involvement in children's learning in the United States and China: Implications for children's academic and emotional adjustment. Child Development, 82(3), 932-950. doi:10.1111/j.1467-8624.2011.01582.x

Child Welfare Information Gateway. (2019). Parent education to strengthen families and reduce the risk of maltreatment. Washington, DC: U.S. Department of Health and Human Services, Children's Bureau. www.childwelfare.gov/pubPDFs/parented.pdf adresinden erişildi.

Claxton, G. (2009). Cultivating positive learning dispositions. H. Daniel, H. Lauder ve J. Porter (Ed.), Educational theories, cultures and learning: A critical perspective içinde. Abingdon: Routledge.

Collins, C. L. ve Fetsch, R. J. (2012). A review and critique of 16 major parent education programs. Journal of Extension, 50 (4), 1-17.

Curtiss, S., Pearson, J., Akamoğlu, Y., Fisher, K., Snodgrass, M., Meyer, L., ... Halle, J. W. (2015). Bringing instructional strategies home: Reaching families online. Teaching Exceptional Children, 48(3), 159-167.

Çayak, S. (2013). Öğretmen-veli işbirliği ile ilkokul öğrencilerinin sınıf içindeki istenmeyen davranışları arasındaki ilişki. (Yayımlanmamış yüksek lisans tezi). Trakya Üniversitesi, Edirne.

Çubukcu, F. (2009). Learner autonomy, self-regulation and metacognition. International Electronic Journal of Elementary Education, 2(1), 53-64.

DeSpain, S. N., Conderman, G. ve Gerzel-Short, ,L. (2018). Fostering family engagement in middle and secondary schools. The Clearing House, 91(6), 236-242.

DeVito, J.A. (2011). Essentials of Human Communication (7. bs.). London: Pearson.

Dunn, R., Honigsfeld, A., Doolan, L.S., Bostrom, L., Russo, K., Schiering, ... Tenedero, H. (2009). Impact of learning-style instructional strategies on students' achievement and attitudes: Perceptions of educators in diverse institutions. The Clearing House: A Journal of Educational Strategies, Issues and Ideas. 82(3), 135-140. doi: 10.3200/TCHS.82.3.135-140.

Dunni R. ve Honigsfeld, A. (2013). Learning styles: What we know and what we need. The Educational Forum, 77, 225-232. doi: 10.1080/00131725.2013.765328

Durukan, E. (2013). Türkçe ögretmen adaylarının ögrenme stilleri ve ögrenme stratejileri arasındaki ilişsi. Turkish Studies, 8(1), 1307-1319.

Edwards, R. ve Gillies, V. (2011). Consumers, commonplace or pioneers? Navigating the contemporary class politics of family, parenting skills and education. Ethics and Education, 6(2), 141-154.

Erdoğan, Ç. ve Demirkasımoğlu, N. (2010). Ailelerin eğitim sürecine katılımına ilişkin öğretmen ve yönetici görüşleri. Educational Administration: Theory and Practice, 16(3), 399-431.

Evin Gencel, I. ve Köse, A. (2011). Relationship between the prospective science teachers learning styles, learning and study strategies and self-efficacy beliefs in science teaching. Journal of Theory Practice in Education, 7(2), 311-333. 
Fan, X. ve Chen, M. (2001). Parental involvement and students' academic achievement: A meta-analysis. Educational Psychology Review, 13(1), 1-22. doi:10.1023/A:1009048817385.

Fredriksson, U. ve Hoskins, B. (2006). The Pilot Project on Learning to Learn. U. Fredriksson, B. Hoskins, P. Adey, L. Chisholm, B. Csapó, L. S. Grønmo, G. Jedeskog, ve A. Demetriou (Ed). , Learning to Learn Network Meeting Report içinde (s. 27-29), 10 Haziran 2019 tarihinde http://crell.jrc.ec.europa.eu/ download/Conferences/L2Lnw1.pdf erişildi.

Froiland, J. M. ve Davison, M. L. (2014). Parental expectations and school relationships as contributors to adolescents' positive outcomes. Social Psychology of Education, 17(1), 1-17. doi: 10. 1007/s11218-013-9237-3

Garcia, V. T., Fernandez, B. G. ve Ruiz-Gallardo, J. R. (2018). Home-based family involvement and academic achievement: a case study in primary education. Educational Studies, 44(3), 361-375.

Garst, B. A. ve McCawley, P. F. (2015). Solving problems, ensuring relevance, and facilitating change: The evolution of needs assessment within cooperative extension. Journal of Human Sciences and Extension, 3(2), $26-47$.

Gettinger, M. ve Walter, M. J. (2012). Classroom strategies to enhance academic engaged time. In S. L. Christenson, A. L. Reschly ve C. Wylie (Ed.), Handbook of research on student engagement içinde (ss. 653-673). New York, NY: Springer.

Gillies, V. (2007). Marginalised mothers: Exploring working class experiences of parenting. London: Routledge.

Gonzalez-DeHass, A. R. ve Willems, P. P. (2016). Nurturing self-regulated learners: teacher, peer, and parental support of strategy instruction. The Educational Forum, 80(3), 294-309. doi: 10.1080/00131725.2016.1173751

Goodall, J. (2018). Learning-centered parental engagement: Freire reimagined. Educational Review. 70(5), 603621.

Goodall, J. ve Montgomery, C. (2014). Parental involvement to parental engagement: A continuum. Educational Review, 66 (4), 399-410.

Göktürk, S. ve Dinçkal, S. (2018). Effective parental involvement in education: experiences and perceptions of Turkish teachers from private schools. Teachers and Teaching, 24(2). 183-201.

Green, C.L., Walker, J.M.T, Hoover-Dempsey, K.V. ve Sandler, H.M. (2007). Parents' motivations for involvement in children's education: An empirical test of a theoretical model of parental involvement. Journal of Educational Psychology, 99(3), 532-544.

Grønmo, L. S. (2006). Learning (How) to Learn. U. Fredriksson, B. Hoskins, P. Adey, L. Chisholm, B. Csapó, L. S. Grønmo, G. Jedeskog, ve A. Demetriou (Ed). , Learning to Learn Network Meeting Report içinde (s. 2729), 10 Haziran 2019 tarihinde http://crell.jrc.ec.europa.eu/ download/Conferences/L2Lnw1.pdf erişildi.

Gubbins, V. ve Otero, G. (2018). Determinants of parental involvement in primary school: Evidence from Chile. Educational Review, doi: 10.1080/00131911.2018.1487386

Güven, M. (2004). Öğrenme stilleri ile öğrenme stratejileri arasındaki ilişki. Eskişehir: Anadolu Üniversitesi Yayınları.

Habok, A. (2015). Learning to learn in years 1 and 2 of Hungarian primary schools. Education, 43(2), 653-673. doi: 10.1080/03004279.2013.783875

Hester, H. (1989). Start at home to improve home-school relations. NASSP Bulletin, 73(513), $23-27$.

Hill, N. E. ve Chao, R. K. (2009). Families, schools, and the adolescent: Connecting research, policy, and practice. New York: Teachers College Press.

Hill, N. E. ve Tyson, D. F. (2009). Parental involvement in middle school: A meta-analytic assessment of the strategies that promote achievement. Developmental Psychology, 45(3), 740-63. doi:10.1037/a0015362 
Hill, N. E., Whiterspoon, D. P. ve Bartz, D. (2018). Parental involvement in education during middle school: Perspectives of ethnically diverse parents, teachers, and student. The Journal of Educational Research, 111(1), $12-27$.

Hoover-Dempsey, K. V. ve Sandler, H. M. (1995). Parental involvement in children's education: Why does it make a difference? Teachers College Records, 97(2), 310-331.

Hoover-Dempsey, K., Walker, J., Sandler, H., Whetsel, D., Green, C., Wilkins, A. ve Closson, K. (2005). Why do parents become involved? Research findings and implications. The Elementary School Journal, 106 (2), 105-130. doi:10.1086/499194.

Horino, M. ve Ichikawa, S. (1997). Learning motives and strategies in high- school students' English learning. Japanese Journal of Educational Psychology, 45(2), 140-147.

Hornby, G. (2011). Parental Involvement in Childhood Education: Building Effective School-Family Partnerships. New York: Springer.

Hornby, G. ve Blackwell, I. (2018). Barriers to parental involvement in education: An update. Educational Review, 70(1), 109-119.

Hornby, G. ve Lafaele, R., 2011. Barriers to parental involvement in education: An explanatory model. Educational Review, 63(1), 37-52.

Jahanbakhsh, R. (2012). Learning styles and academic achievement: A case study of Iranian high school girl's students. Procedia-Social and Behavioral Sciences, 51, 1030-1034.

Jeynes, W. H. (2007). The relationship between parental involvement and urban secondary school student academic achievement: A meta-analysis. Urban Education, 42(1), 82-110.

Jeynes, W. H. (2014). Parental involvement that works...Because it's age-appropriate. Kappa Delta Pi Record, 50(2), 85-88. doi: 10.1080/00228958.2014.900852

Jeynes, W. H. (2018). A practical model for school leaders to encourage parental involvement and parental engagement. School Leadership ve Management, 38(2), 147-163. doi: 10.1080/13632434.2018.1434767

Jezierski, S. ve Wall, G. (2017). Changing understandings and expectations of parental involvement in education. Gender and Education. 31(7), 811-826. doi: 10.1080/09540253.2017.1332340

Jodl, K.M., Michael, A., Malanchuk, O., Eccles, J.S. ve Sameroff, A. (2001). Parents' roles in shaping early adolescents' occupational aspirations. Child Development, 72 (4), 1247-1265.

Johnson, A. P. (2005). A Short Guide to Action Research (2. bs). Boston: Pearson / Allyn and Bacon.

Kanadlı, S. (2016). A meta-analysis on the effect of instructional designs based on the learning styles models on academic achievement, attitude and retention. Educational Sciences: Theory and Practice, 16(6), 2057-2086.

Keating, D. P. (2004). Cognitive and brain development. R. M. Lerner ve L. Steinberg (Ed.), Handbook of adolescent psychology (2. bs.) içinde (s. 45-84). Hoboken, NJ: Wiley.

Keijsers, L. (2018). The development of parental monitoring during adolescence: A meta-analysis. European Journal of Developmental Psychology 16 (5), 552-580. doi:10.1080/17405629.2018.1476233

Keith, T. Z., Keith, P. B., Kimberly, J. Q., Sperduto, J., Santillo, S., ve Killings, S. (1998). Longitudinal effects of parent involvement on high school grades: similarities and differences across gender and ethnic groups. Journal of School Psychology, 36(3), 335-363.

Kigobe, J., Ghesquiere, P., Ng'Umbi, M. ve Leeuwen, K. V. (2018). Parental involvement in educational activities in Tanzania: understanding motivational factors. Educational Studies. 45(5), 613-632.

Kim, S. W. ve Hill, N. E. (2015). Including fathers in the picture: A meta- analysis of parental involvement and students' academic achievement. Journal of Educational Psychology, 107(4), 919-934. 
Kreider, H., Caspe, M., Kennedy, S., ve Weiss, H. (2007). Family involvement in middle and high school students' education. 20 Haziran 2019 tarihinde http://www.hfrp.org/publications-resources/publicationsseries/familyinvolvement-makes-a-difference/family-involvement-in-middle-and-high-schoolstudents education adresinden erişildi.

Lareau, A. (2003). Unequal childhoods: Class, race, and family life. Berkeley, CA: University of California Press.

Lauria, J. (2010). Differentiation through learning-style responsive strategies. Kappa Delta Pi Record, 47 (1), 2429. doi: 10.1080/00228958.2010.10516556

Lawson, M. A. (2003). School-family relations in context: Parent and teacher perceptions of parent involvement. Urban Education, 38 (1), 77-133.

Lerner, R. M. ve Steinberg, L. D. (2009). Individual bases of adolescent development R. M. Lerner, ve L. D. Steinberg (Ed.), Handbook of adolescent psychology içinde (s.3-14). Hoboken, NJ: Wiley.

Li, H. ve He, Q. (2016). Ambiguity tolerance and perceptual learning styles of Chinese EFL learners. English Language Teaching, 9(6), 213-222.

Lionetti, F., Palladino, B. E., Passini, C. M., Casonato, M., Hamzallari, O., Ranta, M., ... ve Keijsers, L. (2018). The development of parental monitoring during adolescence: A meta-analysis. European Journal of Developmental Psychology, 16(5), 1-29.

Matejevic, M., Jovanovic, D. ve Jovanovic, M. (2014). Parenting style, involvement of parents in school activities and adolescents' academic achievement. Procedia - Social and Behavioral Sciences, 128, 288-293. doi:10.1016/j.sbspro.2014.03.158

McGill, R. K., Hughes, D., Alicea, S. ve Way, N. (2012). Academic adjustment across middle school: The role of public regard and parenting. Developmental Psychology, 48 (4), 1003-1018. doi: 10.1037/a0026006.

Mertler, C. A. (2006). Action Research: Teachers as Researchers in the Classroom. UK: Sage Publications.

Miles, M. B. ve Huberman, A. M. (1994). Qualitative Data Analysis (2. bs.). Thousand Oaks, CA: Sage Publications.

Mills, G. E. (2003). Action research: A guide for the teacher researcher (2. bs.). New Jersey: Merrill Prentice Hall

Moreno, A. ve E. Martin (2007). The Development of Learning to Learn in Spain. The Curriculum Journal, 18(2), 175-193.

Moroni, S., Dumont, H., Trautwein, U., Niggli, A. ve Baeriswyl, F. (2015). The need to distinguish between quantity and quality in research on parental involvement: The example of parental help with homework. The Journal of Educational Research, 108(5), 417-431. doi: 10.1080/00220671.2014.901283

Murayama, K. (2003). Learning strategy use and short- and long-term perceived utility. Japanese Journal of Educational Psychology, 51, 130-140.

Noel, A., Stark, P. ve Redford, J. (2016). Parent and family involvement in education. 18 Haziran 2019 tarihinde http://nces.ed.gov/pubsearch adresinden erişildi.

Olmstead, C. (2013). Using technology to increase parent involvement in schools. TechTrends, 57 (6), 28-37.

Özgan, H. ve Aydın, Z. (2010). Okul-aile işbirliğine ilişkin yönetici, öğretmen ve veli görüşleri. E-Journal of New World Sciences Academy, 5(3), 1169-1189.

Park, S. ve Holloway, S. D. (2013). No parent left behind: Predicting parental involvement in adolescents' education within a sociodemographically diverse population. The Journal of Educational Research, 106(2), 105-119.

Patall, E. A., Cooper, H. ve Robinson, J. C. (2008). Parent involvement in homework: A research synthesis. Review of Educational Research, 78(4), 1039-1101. doi:10.3102/0034654308325185 
Pino-Pasternak, D. ve Whitebread, D. (2010). The role of parenting in children's self-regulated learning. Educational Research Review, 5(3), 220-242. doi:10.1016/j.edurev.2010.07.001

Porsuk, A. ve Kunt, M. (2012). Denizli merkez ilköğretim okullarındaki okul aile ilişkilerinde karşılaşılan sorunlar üzerine yönetici görüşleri. Pamukkale Üniversitesi Eğitim Fakültesi Dergisi, 31, 203-218.

Rao, Z. (2002). A close look at the Chinese cultural influence on students' learning styles and strategies. Asian Englishes, 5(1), 40-63. doi: 10.1080/13488678.2002.10801088

Robledo, P. ve J. N. García. (2006). Psychological Factors of Parents of Students with Learning Difficulties: Revision of Empirical Studies. J. D. U. Arciniega ve P. M. Gonzalez (Ed.), Necesidades Educativas Especiales, Contextos Desfavorecidos y Apoyo Social içinde (s.225-235). Badajoz: Psicoex.

Rogers, M. A., Theule, J., Ryan, B.A., Adams, G. R. ve Keating, L. (2009). Parental involvement and children's school achievement. Canadian Journal of School Psychology, 24(1), 34-57.

Sadi, O. ve Uyar, M. (2013). The relationship between self-efficacy, self-regulated learning strategies and achievement: A path model. Journal of Baltic Science Education, 12(1), 21-33.

Saks, K. ve Leijen, A. (2018). The effeciency of prompts when supporting learner use of cognitive and metacognitive strategies. Computer Assisted Language. 32(1-2), 1-16. doi: https://doi.org/10.1080/09588221.2018.1459729

Sato, J. (1998). Effects of learner's perception of utility and costs, and learning strategy preferences. Japanese Journal of Educational Psychology, 46(4), 367-376.

Schunk, D. H. ve Zimmerman, B. J. (2008). Motivation and self-regulated learning: Theory, research, and applications. New York, NY: Lawrence Erlbaum Associates.

Sha, L., Looi, C.-K., Chen, W., Sewo, P. ve Wong, L.-H. (2012). Recognizing and measuring self-regulated learning in a mobile learning environment. Computers in Human Behavior, 28(2), 718-728. doi:10.1016/j.chb.2011.11.019

Sheldon, S. B. (2007). Improving student attendance with school, family, and community partnerships. The Journal of Educational Research, 100(5), 267-275.

Shinogaya, K. (2017). Motives, beliefs, and perceptions among learners affect preparatory learning strategies. The journal of Educational Research, 111(5), 612-619.

Smetana, J. G. (2011). Adolescents, families and social development: How teens construct their worlds. New York, NY: Wiley-Blackwell.

Soenens, B. ve Vansteenkiste, M. (2005). Antecedents and outcomes of self-determination in 3 life domains: The role of parents' and teachers' autonomy support. Journal of Youth and Adolescence, 34(6), 589-604. doi:10.1007/s10964-005-8948-y

Spera, C. (2005). A review of the relationship among parenting practices, parenting styles, and adolescent school achievement. Educational Psychology Review, 17(2), 125-146

Stanley, J. L., Vaterlaus, M., Tulane, S. ve Beckert, T. E. (2017). A place for technology in parent education: An exploratory study of parent perceptions. Marriage \& Family Review, 53(8), 811-825.

Starr, L. (2011). A dozen activities to promote parent involvement. 18 Ocak 2019 tarihinde https://www.educationworld.com/a_curr/curr200.shtml adresinden erişildi.

Şad, N. (2012). Investigation of parental involvement tasks as predictors of primary students' Turkish, math and science \& technology achievement. Ĕ̆itim Araştırmaları, 48, 173-196.

Thomas, V., Muls, J., Backer, F. ve Lombaerts, K. (2019). Exploring self-regulated learning during middle school: views of parents and students on parents' educational support at home. Journal of Family Studies. 1-19. doi:10.1080/13229400.2018.1562359. 
Waeytens, K., Lens, W. ve Vandenberghe, R. (2002). Learning to Learn: Teachers' conceptions of their supporting role. Learning and Instruction, 12(4), 305-322.

Walker, J. M. T., Ice, C. L., Hoover-Dempsey, K. V. ve Sandler, H.M. (2011). Latino parents motivations for involvement in their children's schooling: An exploratory study. The Elementary School Journal, 111(3), 409429. doi:10.1086/657653.

Wall, K. (2012). It wasn't too easy, which is good if you want to learn: an exploration of pupil participation and learning to learn. Curriculum Journal, 23(3), 283-305. doi: 10.1080/09585176.2012.703442

Wang, M. ve Eccles, J. S. (2012). Adolescent behavioral, emotional, and cognitive engagement trajectories in school and their differential relations to educational success. Journal of Research on Adolescence, 22(1), 3139. doi:10.1111/j.1532-7795.2011. 00753.x.

Wang, M. ve Sheikh-Khalil, S. (2014). Does parental involvement matter for student achievement and mental health in high school? Child Development, 85(2), 610-625. doi:10.1111/cdev.12153

Weinstein, C. ve Mayer, R. (1986) The Teaching of Learning Strategies. M. Wittrock (Ed.), Handbook of Research on Teaching içinde (s. 315-327). New York: Macmillan.

Wilder Research. (2016). The benefits of parenting education: A review of the literature for the Wilder Parent Education Center. 20 Haziran 2019 tarihinde https://www.wilder.org/wilder-research/research-library/ benefitsparenting-education-review-literature-wilder- parent adresinden erişildi.

Wilder, S. (2014). Effects of parental involvement on academic achievement: A meta-sythesis. Educational Review, 66(3), 377-397.

Williams, K., Swift, J., Williams, H. ve Van Daal, V. (2017) Raising children's self-efficacy through parental involvement in homework, Educational Research, 59(3), 316-334. doi: 10.1080/00131881.2017.1344558

Williams, T.T. ve Sánchez, B. (2013). Identifying and decreasing barriers to parent involvement for inner-city parents. Youth \& Society, 45(1), 54-74.

Wolters, C. A. (2003). Regulation of motivation: Evaluating an underemphasized aspect of self- regulated learning. Educational Psychologist, 38(4), 189-205. doi:10.1207/S15326985EP3804_1

Yazıcı, E. (2004). Öğrenme stilleri ile ilköğretimde beşinci sınıf matematik dersindeki başarı arasındaki ilişki. (Yayınlanmamş yüksek lisans tezi). Selçuk Üniversitesi, Konya.

Yılmaz, D. (2011). Öğ̌renme stratejilerinin ögřeme stilleri ve bazı değ̌şkenler açısından incelenmesi. (Yayınlanmamış yüksek lisans tezi). Selçuk Üniversitesi, Konya.

Zimmerman, B. J., Bonner, S. ve Kovach, R. (1996). Developing self-regulated learners: Beyond achievement to selfefficacy. Washington, DC: American Psychological Association. 


\section{EXTENDED ABSTRACT}

\section{Introduction}

Parental involvement could be defined in the most general form, as the whole of the activities organized to contribute to the development and education of the children of the parents (Ömeroğlu \& Can Yaşar, 2005 cited in Erdoğan \& Demirkasımoğlu, 2010). When parental involvement classifications and models are examined in the literature (Goodall, 2018; Hester, 1989; Hoover-Dempsey \& Sandler, 1995; Jeynes, 2018; Keith et. al., 1998; Lawson, 2003) it is seen that parental involvement is handled in two ways as school-based and home-based. Especially recently, the term "parental involvement" has often been used for school-based participation and for home-based participation, the concept of "parental engagement" has been used. Studies in the literature show that parental engagement decreases as the age increases (DeSpain, Coderman, \& GerzelShort, 2018; Green, Walker, Hoover- Dempsey, \& Sandler, 2007; Jeynes, 2014; Lawson, 2003; Noel, Stark, \& Redford, 2016; Spera, 2005). One of the important reasons of this is that the age of secondary school onset and adolescent onset of children are close to each other. With the child's transition from primary school to secondary or high school, families should also change the way they involve in the education of adolescents and find more effective ways to support their academic development (Bhargava \& Whiterspoon, 2015; Hill \& Chao, 2009; Hill, Whiterspoon, \& Bartz, 2018; Smetana, 2011). There are few studies on how parental involvement should be in adolescence (Chen \& Gregory, 2009). There are almost no practical studies on how parental engagement should be (Froiland \& Davison, 2014; Jezierski \& Wall, 2017; Matejevic et. al., 2014; Moroni et.al, 2015). Based on these requirements and problems, in the research, it was aimed to realize a parental education study for secondary school students' parents to help to develop their children's learningto-learn skills.

\section{Method}

The research was designed in the form of participatory action research. The research was carried out in two stages. The first stage, which is called the pre-implementation of the action research and at this stage, which is prior to the implementation of action research, the researcher gave general information to the parents about learning to learn, learning styles and learning strategies. The second stage of the research is the action research implementation process to help parents for supporting them to develop their children's learning to learn skills in their learnings. Eight parents and their children formed the participants of the study. The Kolb Learning Styles Inventory II, which was developed by Kolb (1985 cited in Yazıc1, 2004) and adapted to Turkish by Yazıc1 (2004), was used to determine the learning styles of the children of the participating parents. A onetime focus group interview was conducted with the parents to determine their preliminary knowledge of the key concepts in the study on learning to learn. In order to determine the improvement of the parents' skills of using the learning strategies suitable to their children's learning styles, voice recordings of the lessons, field notes, the researcher's diary, "parent support" WhatsApp group, student study papers and the meeting records of the validity-reliability committee were used. A validity and reliability committee was established at the beginning of the implementation process. At the end of the implementation of the action research, semistructured interviews were held in order to determine the views of parents and children. Descriptive analysis was used to analyse the data collected during and after the implementation of the action research.

\section{Results}

The data obtained from the parent education study showed that determining the learning needs, learning objectives and learning topics that were appropriate to these needs by taking into consideration the literature and parent opinions was important. The motivation activities used in parent education study increased the self-confidence of the parents, make them feel sufficient in terms of their knowledge, active participation in the lesson and continue. It was seen that parents and their children prefer to use learning strategies appropriate to their learning styles during the implementation of the parent education study. The data obtained from voice recordings of the lessons, field notes, "parent support" WhatsApp group, student study papers and interviews with both parents and their children during and at the end of the implementation process showed that this study increases the academic achievement of children. The parent education study positively affected not only 
academic achievement but also attitudes towards learning, active participation and self-efficacy perceptions. According to the findings obtained from the study, it can be said that together with the implementation of a support study based on learning styles and more support by their families were effective on the academic success and relevant affective characteristics of the children. Parents' self-confidence also increased with the parent education study and they stated that they would continue similar support activities with their children after the research.

\section{Conclusion}

As the secondary school students' behaviours change with adolescence, parents confuse about how they can support their children's learning. This action research study's results show that parent education studies can be designed to help families understand the individual needs and development of their children, to provide tools and strategies aimed to prevent adolescents' decline in academic performance and to increase positive outcomes for children and their parents. The action research in the study was implemented by focusing on the first level of learning to learn taking into account that the participants have no prior knowledge of learning to learn and due to the depletion of resources (academic school year ended) during the implementation process. For parents and children who are more advanced in learning to learn, parent education studies can be organized focusing on the later stages of learning to learn. It is important that parental engagement and children's learning skills are developed at an early age at school. For this reason, it is thought that carrying out a similar study with preschool teachers, parents and children will contribute to the field of study. 